\title{
SciencesPo
}

\section{NEGATIVE INTEREST RATES, BANK PROFITABILITY AND RISK-TAKING}

Whelsy Boungou 
EDITORIAL BOARD

Chair: Xavier Ragot (Sciences Po, OFCE)

Members: Jérôme Creel (Sciences Po, OFCE), Eric Heyer (Sciences Po, OFCE), Lionel Nesta (Université Nice Sophia Antipolis), Xavier Timbeau (Sciences Po, OFCE)

\section{CONTACT US}

OFCE

10 place de Catalogne | 75014 Paris | France

Tél. +33144185424

www.ofce.fr

\section{WORKING PAPER CITATION}

This Working Paper:

Whelsy Boungou

Negative Interest Rates, Bank Profitability and Risk-taking

Sciences Po OFCE Working Paper, $\mathrm{n}^{\circ}$ 10/2019.

Downloaded from URL : www.ofce.sciences-po.fr/pdf/dtravail/WP2019-10.pdf

DOI - ISSN 


\title{
ofce
}

\section{SciencesPo}

\section{ABOUT THE AUTHORS}

Whelsy Boungou, LAREFI - University of Bordeaux

Email Address: whelsy.boungou@u-bordeaux.fr

\begin{abstract}
Using a panel dataset of 2442 banks operating in the $28 \mathrm{EU}$ countries over the period from 2011 to 2017, this paper aims to assess the impact of negative interest rates on banks" profitability and risk-taking. Using dynamic panel models, we find that the effect of negative interest rates on banks' margins is stronger compared to an environment of positive rates. We notice that negative rates have squeezed banks' net interest margins. We also find that banks have offset the effects on margins by increasing non-interest income. Furthermore, negative interest rates contributed to a reduction in banks' risk-taking. Finally, we note that the effects of negative rates on profitability and risk-taking differ among banks, depending on their specific balance sheet characteristics.
\end{abstract}

\section{KEY WORDS}

Negative Interest Rates, Bank Profitability, Bank Risk-Taking, European Union countries, Dynamic Panel Data Model.

JEL

E43, E52, E58, G21. 



\title{
Negative Interest Rates, Bank Profitability and Risk-taking
}

\author{
Whelsy Boungou*
}

April 2019

\begin{abstract}
Using a panel dataset of 2442 banks operating in the $28 \mathrm{EU}$ countries over the period from 2011 to 2017, this paper aims to assess the impact of negative interest rates on banks' profitability and risk-taking. Using dynamic panel models, we find that the effect of negative interest rates on banks' margins is stronger compared to an environment of positive rates. We notice that negative rates have squeezed banks' net interest margins. We also find that banks have offset the effects on margins by increasing non-interest income. Furthermore, negative interest rates contributed to a reduction in banks' risk-taking. Finally, we note that the effects of negative rates on profitability and risk-taking differ among banks, depending on their specific balance sheet characteristics.
\end{abstract}

JEL: E43, E52, E58, G21.

Keywords: Negative Interest Rates, Bank Profitability, Bank Risk-Taking, European Union countries, Dynamic Panel Data Model.

\footnotetext{
* This research was undertaken while I was at OFCE - Sciences Po, which I thank for its hospitality. I would like to thank Paul Hubert for his invaluable comments and suggestions during the preparation of this paper. I thank Stephane Dees, Laurent Weill, Kaspar Zimmermann, Andrea Polo and the participants of OFCE - Sciences Po and LAPE seminars for helpful comments. I also thank Corentin Laffitte for excellent research assistance. Any remaining errors are mine. LAREFI - University of Bordeaux, France. Contact: whelsy.boungou@u-bordeaux.fr
} 
«By and large, our negative interest rate policy has been a success. [...]

We haven't seen bank profitability go down. ${ }^{1}$ (Mario Draghi)

\section{Introduction}

Since the 2008-2009 Global Financial Crisis (GFC), many central banks have implemented a range of unconventional monetary instruments (including large scale asset purchases and forward guidance) to address low inflation and economic growth. Since 2012, six central banks in Europe ${ }^{2}$ and the Bank of Japan gradually introduced the negative interest rates policy (NIRP). According to Cœuré (2016), the implementation of negative rates ${ }^{3}$ intended to increase the supply of credit by taxing banks' excess reserves at the central bank. This should lead to a reduction in financing costs for both banks and borrowers and thus to an increase in supply and demand for loans and in fine, to improve economic growth4.

This unprecedented non-standard monetary policy measure has raised at least two concerns about its potential effects on banks' profitability and risk-taking. First, the introduction of negative rates could hinder the transmission of monetary policy if they compress banks' interest margins and thus their profitability. Second, in response to the effects on margins, banks could either reduce the share of non-performing loans ${ }^{5}$ in their balance sheets or seek other more profitable assets than bank credit ("Search-for-yield") 6 .

However, the effects of negative interest rates on banks margins are not immediately apparent. Banking intermediation is not a level business, based on the interest rate level, but rather a spread business, based on the difference between credit and deposit interest rates. Bank lending decisions are driving by this interest rate spread. Thus, the reduction in credit interest rates from 5 to $4 \%$ (and deposit rates from 4 to 3\%) should have no effect on banks' profit. However, there may be a threshold effect when interest rates fall below $0 \%$, given that banks are reluctant to apply negative interest rates to savers' deposits. Knowing that cash offers a zero return, a negative deposit interest rate would lead savers to withdraw their deposits due to the negative nominal return.

The bank to apply negative deposit interest rates risks losing customers to other banks. By refusing to pass on negative interest rates on customer deposits, banks' profits related to maturity transformation will be negatively affected (Hannoun, 2015). Thus, the decline in bank margins could reduce bank's profitability, reduce their equity capital and jeopardize their financial stability (Zimmermann, 2019). As a result, banks can compensate for the decline in the lending rate and the implicit compression of margins by: (i) increasing fees and

\footnotetext{
1 At the Conference on "Rethinking Macroeconomic Policy IV", organized on 12 October 2017 by Peterson Institute for International Economics (PIIE) in Washington D.C.

2 Bulgaria,Denmark, Euro Area, Hungary, Sweden, Switzerland.

3 Negative interest rate on the deposit facility of the European Central Bank.

4 See Blot and Hubert (2016); Jobst and Lin, (2017); Angrick and Nemoto, (2017); Madaschid and Nuevo, (2017).

5 Negative rates should increase the solvency of non-financial agents, by encouraging a reduction in nonperforming loans on banks' balance sheets.

${ }^{6}$ See among others, Rajan (2006); Gambacorta (2009); Hannoun (2015).
} 
commissions (Blot and Hubert, 2016; Adrian et al. 2017); (ii) reducing operating expenses and cost to income ratio (Scheiber et al. 2016).

Against this background, the aim of this paper is to study the impact of negative interest rates on European banks' profitability and risk-taking. This paper has three objectives: first, assess whether the level of interest rates (positive and negative) affects banks' interest margins; second, to analyze how bank profit have responded to the effects on interest margins; third, to assess whether negative rates have changed banks' incentives to take risks.

The contribution of this paper is fourfold. First, while most existing studies on negative rates focus only on individual countries 7 , our study covers the 28 countries of the European Union ${ }^{8}$. Second, we look at the effects of negative rates on banks' profitability and risktaking. Third, we compare the effects of negative rates and positive rates on banks' interest margins. Fourth, we estimate the influence of profitability on risk-taking in a negative interest rate environment.

We use a panel dataset of 2442 banks operating in the 28 member countries of the European Union over the period 2011-2017. In order to estimate the effect of negative rates on bank margins, we use net interest margins as a proxy. The objective is to examine whether there is a threshold effect around zero in the link between the policy rate and net interest margins. Then, using profit before tax and return on average assets, we analyze how banks have reacted to this threshold effect. We also look at the effects of negative rates on banks' risktaking. To measure risk-taking, we use three measures: (i) non-performing loans which are an indicator of the risk taken by the bank over a period of time (stock); (ii) provisions, the bank must establish provisions when it holds doubtful receivables on its balance sheet (flows); (iii) z-score which measures the bank's overall solvency. Our analysis also takes into account the usual determinants of banks' profitability and risk-taking. For instance, we control market concentration that could affect bank behavior. The Herfindahl-Hirschman Index, which measures market concentration, reports on the extent to which banks rely on their market power to make profits (and/or take risks).

The main empirical challenge of this paper is that monetary policy may be endogenous to bank profitability and risk-taking. Indeed, the previous literature has noted that this endogeneity bias can be linked either to the existence of a reverse causality between monetary policy and bank profitability (risk-taking), and/or to the bias of omitted variables9. To overcome this potential endogeneity bias, we include a lagged dependent variable and use dynamic panel estimates (System GMM) which considers persistence effects (profit and risk), bank-specific and macroeconomic determinants.

We find that there is a threshold effect at zero. Indeed, the effects of negative rates are more significant on banks' margins than positive rates. We also note that negative rates have reduced banks' margins. In response to this reduction in margins, banks increased non-

\footnotetext{
7 Austria (Kerbl and Sigmund, 2017), Sweden and Denmark (Madaschi and Nuevo, 2017), Switzerland (Basten and Mariathasan, 2018), Italy (Bottero et al. 2019).

8 Our study is close to that of Claessens et al. (2018), but they only look at the effects of low interest rates on banks' interest margins and profitability.

9 See among others, Athanasoglou et al. (2008); Delis and Kouretas (2011); Maddaloni and Peydró (2011).
} 
interest income, justifying the absence of an effect on bank profits (measured by profit before tax and return on average assets). Indeed, during the implementation of negative rates, banks took fewer individual risks and reduced the proportion of non-performing loans on their balance sheets. Indeed, negative rates would encourage an improvement in the solvency of non-financial agents and, in turn, a reduction in the share of non-performing loans. To explain our findings, we look at the influence of profitability on banks' risk-taking in a context of negative rates. We find that during the implementation of negative rates, banks did not take more risks despite a contraction of NIM. We also notice that the effects of negative rates on profitability and risk-taking differ among banks, depending on their specific balance sheet characteristics (size and liquidity).

One potential concern with this set-up is that monetary policy is measured at the annual frequency. This is a common issue for similar studies. Following Claessens et al. (2018), we use the yearly average of the monthly policy rate observations. We test the robustness of this assumption by using the last observation of each year. We find similar results to those of the benchmark estimates. In addition, the use of yearly data is that it is difficult to disentangle the effect of negative interest rates from the other unconventional monetary policy measures. However, this problem would be particularly acute if liquidity measures, such as longerterm targeted refinancing operations (TLTROs) or Public Sector Purchase Programme (PSPP), were correlated with changes in the deposit facility rate. This is not the case over our sample, which should attenuate this potential bias.

In addition, our results are robust to various sensitivity analyses, such as removing countries from our sample. As another sensitivity analysis, we look at the effects of the interbank market rate on banks' profitability and risk-taking. Indeed, in the majority of countries that have applied negative rates, the interbank market rate fell below zero a few months after their implementation.

The remainder of this paper is organized as follows. The second part describes the related literature. The third part presents the data. The fourth one describes the empirical strategy. Subsequently, we present and comment the empirical results. The last section concludes.

\section{Background}

\subsection{Related literature}

The recent financial crisis has highlighted the different types of risks to which the financial sector and, ultimately, the real economy are exposed. An important aspect is the role of low and negative interest rates, as a result unconventional monetary policy, on banks' behavior. In this section, we briefly review the literature on the relationship between a low or negative interest rate environment and bank behavior. In the first subsection, we present the relationship between interest rates and banks' profitability. Finally, we expose the one between (low or) negative rates and banks' risk-taking.

\subsubsection{Interest rates and banks' profitability}


Currently, there is no consensus on the effects of interest rate effects on bank profitability. On the one hand, several studies have shown that interest rates could have negative effects on bank profitability (Genay and Podjasek, 2014; Busch and Memmel, 2017; Dell'Ariccia et al. 2017; and many others). On the other hand, some authors find opposite effects on bank profitability (among others, Scheiber et al. 2016; Jobst and Lin, 2017; Kerbl and Sigmund, 2017; Madaschid and Nuevo, 2017; Basten and Mariathasan, 2018).

Genay and Podjasek (2014) study the impact of a low interest rate environment on bank profitability. The authors show that low interest rates are associated with lower profitability for banks, particularly for smaller institutions ${ }^{10}$. In the same spirit, using Difference-inDifference methodology Molyneux et al. (2018) find that during the implementation of negative interest rates bank margins and bank profits declined. They also document that this negative effect is greater for smaller banks.

Conversely, Scheiber et al. (2016) provide opposite evidence on the effects of negative rates on banks. The authors investigate the profitability of banks in three European countries (Denmark, Sweden and Switzerland) during a period of very low and negative interest rates (from 2010Q1 to 2015Q4). They find that in these countries, negative interest rates have so far not resulted in a significant reduction of bank profitability and especially of net interest income. According to them, banks' profitability in Denmark, Sweden and Switzerland has remained sound, and we do not observe significant a rush-to-cash effect on banks' customers. Moreover, focusing on the Danish and Swedish banks, Madaschi and Nuevo (2017) come up with similar conclusions. They find that banks' profitability has continued to increase despite the implementation of negative rates and banks' reluctance to introduce negative deposit rates.

Among others (Shin, 2016, Altavilla et al. 2017; Arteta et al. 2018), the divergence in the effects of negative rates on bank profitability can be explained by: (i) the impact of monetary policy on macroeconomic conditions; (ii) the ability of banks to diversify their income sources (Scheiber et al. 2016; Arseneau, 2017 and many others).

\subsection{2. (Low or) Negative rates and banks' risk-taking}

As the implementation of negative rates is recent, there are hardly any studies in the literature that analyze the effects of negative interest rates on bank risk-taking in Europe (except Heider et al. 2018;Basten and Mariathasan, 2018). Most of the literature focuses on the low rate environment. To the best of our knowledge, we are the first to analyze the effects of negative rates on the risk-taking of banks operating in the 28 member countries of the European Union.

For Borio and Zhu (2012), the implementation of unconventional monetary policies over a long period of time would affect banks' risk perception. The idea that monetary policy would encourage banks to take more risks has spread widely in recent years ${ }^{11}$. Indeed, lax monetary

\footnotetext{
10 Borio et al. (2017) also find that a low interest rate environment erode bank profitability.

11 The idea that a low interest rate environment would influence banks' risk perception can be traced back to Hancock (1985) and Aharony et al. (1986). They find that in the short term, low interest rates could reduce the
} 
policies are a classic ingredient of financial crises (Bordo and Jeanne, 2002; Ahrend et al. 2008; Gambacorta, 2009; Bordo and Landon-Lane, 2013). Although the causes of the GFC have been multiple, the literature has often argued that monetary policy was one of the factors contributing to excessive banks' risk-taking (Taylor, 2009). In addition, some studies find a significant relationship between low interest rates and banks' risk-taking, which underlines a different dimension of the transmission mechanism of monetary policy: the risk-taking channel (Gambacorta, 2009; Adrian and Shin, 2010; Borio and Zhu, 2012; Dell'Ariccia et al. 2017) ${ }^{12}$.

Indeed, long-term low or negative interest rates would encourage financial intermediaries to increase the share of risky investments in their portfolios and reduce their share of stable resources, respectively on the assets and on the liabilities side. Similarly, Maddaloni and Peydró (2011) corroborate this relationship between accommodative monetary policy and loosening credit conditions. Similarly, by using Difference-in-Difference methodology Heider et al. (2018) examine in the Euro Area the transmission of negative policy rates to the real economy via the supply of bank credit over the period from January 2013 to December 2015. They show that in the presence of negative rates, banks take more risks and provide less credit to the real economy.

Several studies in the risk-taking literature tend to explain how the interest rate structure would encourage excessive risk-taking by banks. For some authors, the effects of interest rates on risk-taking depend on the profitability level of banks (Keeley, 1990; Repullo, 2004; Martynova et al. 2015) and for others, on the bank's capitalization level (Camara et al. 2013; Ziadeh-Mikati, 2013; Jiménez et al. 2014; Rahman et al. 2015; Pham, 2016; Dell' Ariccia et al. 2017).

\subsection{The hypotheses}

\section{Hypothesis 1: Negative interest rates impact banks' profitability.}

We analyze the relationship between negative interest rates and bank profitability. Since the implementation of negative rates is recent, there is currently little (but growing) work in the literature that analyses this relationship. The results of this literature are not unanimous as to the effects of negative rates on bank profitability. On the one hand, some papers show that negative rates have negative effects on profitability (among others, Kerbl and Sigmund, 2017; Molyneux et al. 2018). On the other hand, other studies find the opposite results (Scheiber et al. 2016; Jobst and Lin, 2017; Madaschid and Nuevo, 2017; Basten and Mariathsan, 2018). We complement these studies by assessing the effects of negative rates on bank profitability, measured with bank margins (NIM) and bank profit (profit before tax and return on assets). With NIM, we estimate whether there is a threshold effect at zero (when interest rates are below zero) and profit before tax and return on assets allow us to analyze the banks' response. Therefore, we expect the negative effects of negative interest rates on bank profitability.

profitability of commercial banks. Therefore, to maintain their level of profitability, banks could take riskier positions.

12 Borio and Zhu (2012) are the first to use the term "risk-taking channel" and to explain its different aspects. 
Hypothesis 2: Negative interest rate would affect banks incentives to take risks.

Using this second hypothesis, we assess whether, since their implementation, negative rates have favored an increase in risk-taking. The relationship between negative rates and banks' risk-taking has also been poorly documented. The results of the existing literature show that negative rates would have favored an increase in risk-taking, by encouraging banks to substitute their excess reserves in riskier investments (Jobst and Lin, 2017; Heider et al. 2018). Our measures of banks' risk-taking make it possible to accurately assess the effects of negative rates on banks' balance sheets and thus supplement the results of the literature.

\section{Data}

We use a large unbalanced panel dataset to examine the effects of negative interest rates on European banks. In order to achieve this, we assemble a dataset from several sources. Our final database consists of non-consolidated data from 2442 banks ${ }^{13}$ operating in the 28 European countries, including the 19 Euro Area members. We have sorted our database by deleting missing bank data and winsorizing the data at the $1^{\text {st }}$ and 99th percentile level to ensure that outliers do not bias our estimates (for example, when assets are less than zero or non-performing loans are below zero).Our sample allows us to fully assess the effects of the implementation of negative interest rates policy on the profitability and risk-taking. The sample covers 7 years from 2011 to 2017.

The descriptive statistics of the variables used in this study are displayed in Table A. For each variable, the table shows a brief description; the total number of observations available and the data sources are given in the last column. As control variables we use a wide set of bank-specific and macroeconomic variables. Our primary source of data is Orbis Bank Focus, a global database of banks' financial statements and ownership structures maintained by Bureau van Dijk and Moody's Investors Service. Macroeconomic data are taken from several dataset (OECD, central banks, World Bank and Datastream). All our data cover the period 2011-2017. Furthermore, the policy interest rate data come from the central banks of the different countries and/or currency area.

\subsection{Negative interest rates measures}

We study the effects of negative interest rates on European banks. Recently, seven central banks considered that the implementation of negative rates was a necessary complement and reinforcement of existing measures (Table B shows the implementation dates of the central bank rates that turned negative). In fact, in the context of a slump in economic growth and increasing risks of deflation, and with limited support from fiscal and structural policies, they decided, in addition to existing unconventional monetary policy measures, to go into the negative zone and therefore provide additional support (Arteta et al. 2018). The purpose of negative rates, combined with other measures conducted by central banks, is to encourage

\footnotetext{
13 Retail and consumer banks, universal commercial banks, saving banks, cooperative banks, investment banks, wholesale commercials banks, bank holding companies and banks loans.
} 
lending. In Figure 1, we have the evolution between January 2011 and December 2017 of the central bank key rates that went into negative territory.

As a main measure of negative interest rates, we use the annual average of the central bank rate that became negative (i). For example, for the European Central Bank (ECB) we use the deposit facility rate. Furthermore to take into account the change of $i$, we introduce two new variables. Firstly, Dummy variable $\left(D_{N I R P}\right)$ that captures the period of negative interest rate policy. This variable takes the value 1 when $i$ from the year of implementation of the negative rates and following and the value 0 before this period. The vast majority of countries in our sample introduced negative rates in 2014, which is why $D_{\text {NIRP }}$ takes the value 1 from $2014^{14}$. Finally, we also introduce an interaction term $\left(i * D_{\text {NIRP }}\right)$ to check if the impact of policy interest rate on European banks is different when it is negative compared to positive rate. This variable makes it possible to check more precisely the existence of a threshold effect when the $i$ is below zero thus to compare the effects on banks of negative and positive interest rate environments.

\subsection{Profitability measures}

In order to assess the effects of negative rates on bank profitability, we employ three measures of profitability widely used in the literature: banks' margin (net interest margin) and banks' profit (profit before tax and return on average assets) ${ }^{15}$. To compute these determinants of bank profitability ${ }^{16}$, we use the balance sheet of the banks from the Orbis Bank Focus database.

Net interest margin (NIM) determines the profitability of bank loans and increases the current value of bank income (Adrian and Shin, 2010). NIM is measured by net interest income divided by total assets. As a result, higher margins indicate a better asset management quality and therefore the use of assets in a cost-effective manner (Noman et al. 2015). By using NIM as a proxy for bank margins, we verify the presence of a zero threshold effect that could compromise banking intermediation activity. Indeed, this threshold effect could impact banks' margins as they are more reluctant to apply negative rates on savers' deposits. In order to analyze how banks would have reacted to this effect on margins, we use two measures of bank profit: profit before tax and return on average assets. Following Dermirguç and Huizinga (2000); Albertazzi and Gambacorta (2009), we use banks' profit before tax divided by total assets (PROBTA) as a determinant of bank profit and reflects the total revenue of banks. Return on average assets (ROA) is defined as the ratio between net incomes to total assets (Altman, 1977; Altavilla et al. 2017; Bikker and Vervliet, 2018).

\footnotetext{
14 However, Denmark is the first country in the last decade to have introduced negative rates, in 2012, $D_{\text {NIRP }}$ is then set at 1 from 2012. For Sweden, $D_{\text {NIRP }}$ is equal to 1 since 2015. Finally, for Hungary and Bulgaria, $D_{\text {NIRP }}$ takes the value 1 since 2016 .

15 Demirgüç-Kunt and Huizinga, (1999); Artera et al.(2016); Caselli, (2016); Altavilla et al. (2017); Claessens et al. (2018); Kerbl and Sigmund, (2017); Borio and Gambacorta, (2017); Jeon et al. (2018); Molyneux et al. (2018).

16 In the literature, the return on average equity (ROE) is also used as a measure of bank profitability. See for example, Athanasoglou et al. (2008); Trofimov et al. (2018).
} 
Our three proxies of bank profitability are concentric measures. Indeed, in the computation of PROBTA we find mainly both NIM and non-interest income, and ROA takes into account PROBTA (and thus NIM).Therefore, NIM makes it possible to analyze whether there is a threshold effect at zero on banks' margins, while PROBTA and ROA evaluate the banks' responses to the effect on margins.

\subsection{Risk-taking measures}

In this paper, we use three variables to measure bank risk-taking: non-performing loans, provisions and z-score. These measures are commonly applied in the banking literature.

To measure assets quality, we use the non-performing loans ratio (NPLs), which is widely used in the literature as an indicator of the bank's risky behavior ${ }^{17}$. It reflects the quality of the banks' portfolios of loans (Andries et al. 2016). High NPLs would mean that the bank took more risks by granting more loans to potentially insolvent non-financial agents, so that it accumulated higher ex post bad debts in its balance sheet. In addition, we represent also bank risk-taking using credit risk, measured by the ratio of loan loss provisions to gross loans (provisions). This ratio measures the quality of the assets held by the bank, indicating the portion of gross loans that has been provided for but not charged off. Theory suggests that a high ratio (low quality loans) would indicate an increase in the bank's risk-taking and, conversely, a less excessive risk-taking (higher quality loans). Furthermore, the reduction of NPLs in the banks' balance sheets would, all other things being equal, result in a reduction in provisions. Indeed, banking standards (i.e. IFRS 9) require banks to set aside provisions from expected losses over the year. Therefore, the reduction in NPLs should result in a reduction in provisions. Therefore, NPLs and provisions are used to measure risk-taking through the flow and capital stock, respectively.

In addition to our two previous risk-taking measures, we use a global measure of bank solvency: $z$-score ${ }^{18}$. It has been widely used in the risk-taking literature to measure the probability that a bank will fail or go bankrupt ${ }^{19}$. In his method of computation, it combines profitability, leverage, and return volatility in a single measure (Berger et al. 2009). According to Pham (2016), z-score is a measure of individual bank risk and it explicitly compares bank buffers (shareholders' equity and earnings) with its operating risk (volatility of earnings). It equals to the sum of average return on assets (ROA) and equity to total assets ratio (ETA) divided by the standard deviation of ROA $\left(\sigma_{R O A}\right)^{20}$.A higher z-score implies a lower probability of insolvency risk and therefore lower risk-taking. Conversely, a lower zscore (a higher probability of default) indicates a higher risk-taking (Andries et al. 2016). As Beck et al. (2013), we use a three-year rolling time window, rather than the full sample period, to compute the standard deviation of ROA to allow for time variation in the

\footnotetext{
17 See, among others, Jiménez et al. (2013); Espinoza and Prasad, (2010); Delis and Kouretas, (2011); Tabak et al. (2013).

18 In the literature, the z-score is generally attributed to Boyd and Graham (1986); Hannan and Hanweck (1988) and Boyd et al. (1993), although its origins date back to Roy (1952).

${ }^{19}$ See, among others, Čihák and Hesse (2007); Berger et al.(2009); Beck et al. (2013); Nguyen and Boateng, (2015); Andries et al. (2016); Pham, (2016); Jeon et al. (2018).

${ }^{20} \mathrm{z}$-score $=(\mathrm{ROA}+\mathrm{ETA}) / \sigma_{R O A}$
} 
denominator of the z-score. After computing the z-score, we find that the distribution is highly skewed. In order to reduce this asymmetry, we decide to winsorizing the data at the $1^{\text {st }}$ and 99th percentile level and then like Laeven and Levine (2009) and Houston et al. (2010), we take the natural logarithm of the z-score.

\subsection{Bank-specific controls}

As banks' characteristics, we use in our estimates the liquidity (liquid assets to total assets ${ }^{21}$ ), the equity (equity to assets ratio ${ }^{22}$ ), the efficiency (cost to income ratio ${ }^{23}$ ) and the size (natural logarithm of total assets ${ }^{24}$ ), respectively.

As a liquidity of banks proxy, we take liquid assets to total assets. The banks have to hold a percentage of liquid assets in order to meet these short-term obligations in the case of a bank rush. As a result, a higher liquid asset ratio makes the bank more liquid and less vulnerable in the event of a bankruptcy. As other banking characteristics, we use, like Caselli (2016); Borioand Gambacorta (2017), equity to assets ratio as a measure of bank equity. To capture the effect of efficiency, we include a bank's specific controls, namely efficiency measured as the cost to income ratio ${ }^{25}$. This ratio is typically used as an indicator of management's ability to control expenses (Kosmidou et al. 2008). In order to take into account the possible "toobig-to-fail" theory ${ }^{26}$, we include in our regressions bank size, defined as the natural logarithm of total assets ${ }^{27}$.

\subsection{Country-specific controls}

The banking literature suggests that the environment in which banks operate may have effects on their behavior. As a result, the structure of the banking industry and the country's economic situation can affect banks' profitability and risk-taking. We consider the real GDP growth rate and the consumer price index as measures of macroeconomic conditions, the yield curve slope allows other non-conventional measures to be taken into account and the Herfindhal-Hirschman Index as a measure of banking market structure.

Following Delis and Kouretas (2011), we use real GDP growth rate as a control of the business cycle. The annual change of average consumer price index (inflation) is used as a measure of the macroeconomic conditions. As the implementation of negative interest rates was done in parallel with other existing non-conventional monetary policy measures, we treat these confounding events by including the yield curve slope (Spread). It is the difference between the 10-year government bond yield and the three-month interbank rate. Finally, we use the Herfindhal-Hirschman Index (HHI) as a measure of banking market structure. Herfindhal-Hirschman Index (HHI), better known as the Herfindhal Index, is a

\footnotetext{
21 Altavilla et al. (2017); Borio et al.(2017); Molyneux et al. (2018).

22 Athanasoglou et al. (2008); Adrian and Shin (2010); Borio and Gambacorta (2017); Bikker and Vervliet (2018).

${ }^{23}$ Kosmidou, (2008); Kosmidou et al. (2008); Caselli, (2016); Altavilla et al.(2017).

24 Gambacorta (2009); Borio et al. 2017; Bikker and Vervliet (2018).

25 Operating expenses consist mainly of staff salaries and benefits, property management fees and other expenses such as office supplies.

26 Other theories have been raised by Laeven et al. (2016), "unstable banking theory" and "agency cost theory".

27 To ensure comparability across banks, all balance sheet and income statement data is converted to US dollars using the relevant exchange rates at each closing date.
} 
statistical measure of the structure of the banking market. It can take values between 0 and 10 000. This index is commonly accepted as a measure of concentration and it is calculated by squaring the market shares of each competing bank on the market.

\section{Empirical strategy}

\subsection{The empirical model}

To assess the impact of negative interest rate on the profitability and risk-taking of European bank, we estimate the following equation:

$$
Z_{i, k, t}=c+\alpha_{0} Z_{i, k, t-1}+\alpha_{1} M P_{k, t}+\alpha_{2} X_{i, k, t}+\alpha_{3} Y_{k, t}+\theta_{t}+\lambda_{k}+\varepsilon_{i, k, t}
$$

$Z_{i, k, t}$ is the profitability (or risk-taking) measures for bank $i$ in the country $k$ at time $t$. In line with the literature, a dynamic model is adopted, as bank profitability (and risk-taking ${ }^{28}$ ) tends to persist over time, see Athanasoglou et al. (2008); Berger et al. (2009) and Bikker and Vervliet (2018). The level of persistence of the banking performance (and risk-taking) is captured by the coefficient $\alpha_{0}$ of the lagged dependent variable. The negative interest rates variables are entered by $M P_{k, t}$, bank-specific controls are captured by $X_{i, k, t}$, the countryspecific controls is represented in the $Y_{k, t} . \theta_{t}, \lambda_{k}$ and $\varepsilon_{i, k, t}$ are respectively time fixed effect, country fixed effect and idiosyncratic error.

\subsection{Endogeneity issues}

Following Beck and Levine (2004) and Arcand et al. (2015), we start our estimates by regressing our equations with ordinary least squares (OLS). As Klein and Weill (2018) indicate, OLS regressions are not only useful in describing the data but also in providing a first (biased) estimate of the coefficients. Let us remember that the OLS estimator is consistent when the regressors are exogenous and optimal in the class of linear unbiased estimators when the errors are homoscedastic and serially uncorrelated. But, in our analysis previous studies indicate that the relationship between monetary policy, bank profitability and risk-taking may be endogenous because central banks tend to adjust the monetary policy rate according to the observed behavior of banks (Athanasoglou et al. 2008; Gambacorta, 2009; Garcia-Herrero et al. 2009; Delis and Kouretas, 2011; Maddaloni and Peydró, 2011; Michalak, 2012; Martynova et al. 2015; Ioannidou et al. 2015; Borio and Gambacorta, 2017). Consequently, the estimates of OLS may be biased in dynamic models on two points: (i) a potential reverse causality; and (ii) an omitted variable bias ${ }^{29}$ between the independent and dependent variables.

To further mitigate the issue of endogeneity, we decide to apply the generalized method of moments (GMM) developed by Arellano and Bond (1991) and further advanced by Arellano and Bover (1995) and Blundell and Bond (1998) that provides consistent estimation in

\footnotetext{
28 Several studies on the determinants of banking risk suggest that banks' risk-taking behavior is very persistent (see among others, Cordella and Yeyati, 2002; Delis and Kouretas, 2011; Martynova et al. 2015).

29 For more details see, among others, Maddaloni and Peydró, (2011); Delis et al. (2011); Jiménez et al. (2013) and Ioannidou et al. (2015).
} 
dynamic model with lags of dependent variable. It is known as "System GMM"30. With this method, the estimators are designed as dynamic if we have small number of time period ("Small T") and large individuals ("Large N") ${ }^{31}$ that may contain fixed effects and separate from those fixed effects idiosyncratic errors that are heteroskedastic and correlated within but not across individuals.

Analogous to related empirical literature, all bank's specific variables and policy interest rates are treated as endogenous. As suggested by Blundell and Bond (1998), all bank's specific controls, transformed in first differences, are instrumented by their lags in levels. Whereas the country's specific control variables are considered as strictly exogenous (instrumented by themselves). Moreover, we reduce the number of instruments using the collapsing method of Holtz-Eakin et al. (1988). The collapse options create one instrument for each variable and lag distance instead of one for each time period, variable and lag distance. Therefore, the number of instruments is kept below the number of groups (temporal observations) in all our GMM specifications. Following Roodman (2009), we compute robust standard errors ${ }^{32}$ and two-step estimator using Windmeijer (2005) finite sample correction.

\section{The effects of negative interest rates}

This section presents and comments on the results of the study. Our equations have been estimated using the System GMM estimator suggested by Arellano and Bond (1991), which ensures consistency and efficiency provided that residuals of our models are not subject to serial correlation, $\operatorname{AR}(1)$ and $\operatorname{AR}(2)$ tests, and that the instruments used are valid (with the Hansen test). In the first subsection, we assess the effects of negative interest rate on the profitability of banks (Table D). Then, we investigate whether negative rate would have encouraged banks to take excessive risks (Table E). Finally, we look at how, in an environment of negative rates, banks' profitability could influence risk-taking (Table F).

\subsection{On bank profitability}

Equation (2) describes bank net interest margin as a function of policy interest rate and other determinants of bank margins:

$$
N I M_{i, k, t}=c+\alpha_{0} N I M_{i, k, t-1}+\alpha_{1} M P_{k, t}+\alpha_{2} X_{i, k, t-1}+\alpha_{3} Y_{k, t}+\theta_{t}+\lambda_{k}+\varepsilon_{i, k, t}
$$

Where $N I M_{i, k, t}$ is the net interest margin for bank $i$ in the country $k$ at time $t$. Table 1 presents the results of equation (2) which assesses the effects of negative rates on banks' margin. For each proxy of bank profitability (NIM, PROBTA and ROA) ${ }^{33}$, we estimate a pooled OLS equation (first column), with robust standard errors, which allows us to have a first (biased) estimate of our coefficients. Columns 2-4 present our main results with the System GMM

\footnotetext{
30 We use the System GMM estimator because it tends to outperform the Difference GMM estimator in terms of consistency and efficiency as it uses both the difference and the levels equation (Blundell and Bond, 1998).

31 Our sample consists of 2442 banks $(\mathrm{N})$ and 7 periods $(\mathrm{T})$.

32 By testing the heterogeneity between countries with "cluster (country)", we find similar results. Available on request.

33 It should be noted that our 3 proxy measures of bank profitability are concentric measures. Therefore, if negative rates have effects on NIM, these effects must be less important (or even no effect) on PROBTA and ROA.
} 
method. Moreover, in each equation, the coefficients associated with the lagged dependent variables are very significant, which confirms the persistence of banking performance. This means that the banking performance of the previous period significantly influences the banking performance of the current period.

Table 1 also shows that the interest rate is positively and significantly correlated with NIM. These results indicate that the low-interest rate environment has a negative effect on bank margins. These results are broadly consistent with previous analysis (Genay and Podjasek, 2014; Busch and Memmel, 2017; Claessens et al. 2018, and many others). For example, a decrease in the interest rate by central banks (i) of $1 \%$ leads to a NIM reduction of 0.43 percentage point. These results are different from the findings of Altavilla et al. (2017) who show that a decrease in interest rates does not imply a decline in the profitability of banks.

In addition, using equation (2) we analyze the impact of negative rates on bank net interest margin and ultimately compare the effects of interest rate levels (positive and negative) on profitability. We find that during the negative rate implementation period $\left(D_{N I R P}\right)$, European banks experienced deterioration in their NIM (-2.1\%). However, $D_{N I R P}$ does not allow us to define the role played by negative rates in this decline in bank margins. The implication (marginal effect) of negative rates in the decline in bank margins is shown through the coefficient associated with our interaction term $\left(i * D_{\text {NIRP }}\right)$. We document that, ceteris paribus, the effects of interest rates on NIM are larger in a negative rate environment than in a positive interest rate environment as the associated coefficients are $1.02(=0.420+0.60)$ vs. 0.42 . Consequently, negative rates would contribute significantly to the erosion of NIM. The fact that negative interest rates have a greater impact on banks' margins (compared to low and positive rates) probably indicates banks' reluctance to charge negative deposit rate (Kerbl and Sigmund, 2017; Heider et al. 2018; Basten and Mariathasan, 2018). However, these results are opposite to those Madaschi and Nuevo (2017) find that profitability of banks in Sweden and Denmark has continued to improve, even with negative monetary policy rates.

Our results show that negative rates have reduced the margin of European Union banks (measured by NIM). These results also show the presence of a threshold effect when interest rates are below zero. Indeed, we note that the effects of negative rates on margins are greater than those of positive rates. This reduction in margins is due to the fact that banks are more reluctant to apply negative rates on deposits. As a result, equation (3) allows us to analyze the banks' response to the reduction in net interest margins associated with negatives.

Equation (3) describes bank's profit as a function of policy interest rate and other profit determinants:

$$
\text { Profit }_{i, k, t}=c+\alpha_{0} \text { Profit }_{i, k, t-1}+\alpha_{1} M P_{k, t}+\alpha_{2} X_{i, k, t-1}+\alpha_{3} Y_{k, t}+\theta_{t}+\lambda_{k}+\varepsilon_{i, k, t}
$$

WhereProfit $_{i, k, t}$ is the profit before tax (or ROA) for bank $i$ in the country $k$ at time $t$. Furthermore, we show that the level of interest rates has no impact on the banks' profit (Table 1). This result is consistent with Zimmermann's (2019) finding that the gross effect of interest rate levels on bank profits is still unclear. Likewise, we find that negative rates have no effect on bank profits. The absence of significant effects of negative interest rate on banks' 
profit can be attributed to banks' diversified activities and the implementation of additional measures by central banks to limit the potential negative effects of interest rates on banks. In fact, banks increase their non-interest income (fees and commissions) in response to the reduction in their margins. It should be noted that the effect of non-interest income is taken into account in the calculation of PROBTA, hence the absence of any significant effect on banks' profits. The other way of explaining the absence of significant effects is the existence of a potential non-linear relationship between interest rate levels and overall bank performance as mentioned by Borio et al. (2017).

Regarding our banks' specific and country's specific controls, we find similar results to those in the literature. They influence both the margins and profit of banks. The results of the controls are reported in Table D in the Appendix.

\subsection{On bank risk-taking}

Equation (4) explains bank risk-taking from policy interest rate and other determinants:

$$
\operatorname{Risk}_{i, k, t}=c+\alpha_{0} \operatorname{Risk}_{i, k, t-1}+\alpha_{1} M P_{k, t}+\alpha_{2} X_{i, k, t-1}+\alpha_{3} Y_{k, t}+\theta_{t}+\lambda_{k}+\varepsilon_{i, k, t}
$$

With Risk $_{i, k, t}$ is risk-taking measures (NPLs, provision or z-score) for bank $i$ in the country $k$ at time $t$. Table 2 presents the results of equation (4). For each proxy of bank risk-taking, we estimate a pooled OLS equation (first column). The next three columns present our main results with the System GMM method. We note that the coefficient on the lagged dependent variables of risk measures, are highly significant (except for the last column of provisions). These results suggest the persistent character of banking risk as underlined by Delis and Kouretas (2011). It means that the bank risk of previous period influence the bank risk of the current period in a significant way.

The results of equation (4) (reported in Table 2) indicate that the reduction of positive interest rates (i) would reduce banks' risk-taking. Indeed, a $1 \%$ decrease in the interest rate is accompanied by a $2.4 \%$ reduction in the NPLs and a $0.98 \%$ reduction in provisions and a $0.75 \%$ increase in the z-score. As a result, reduction of interest rates would decrease banks' incentives to take risks and improve banks' creditworthiness. Geng et al. (2016) provide similar evidence for Chinese banks. For the authors in the presence of low rates, banks would not want to commit to taking more risks.

In addition, our results show that during the implementation of negative interest rates (D $\left.\mathrm{D}_{\mathrm{NIRP}}\right)$, European banks reduced their risk-taking, in particular by improving the quality of their balance sheet assets. Indeed, in response to the negative rates, the banks of the European Union would not have been encouraged to take more risks. It should also be noted that the improvement in the solvency of non-financial agents, linked to negative interest rates, would encourage a reduction in non-performing loans. Moreover, this reduction in risk-taking can be explained by: (i) the lack of effect of negative rates on banks' profit and (ii) prudential regulation. Indeed, the absence of an effect on banks' profits may justify a lower level of risk. In addition, the various prudential policies aim to strengthen their resilience in the event of a negative shock (and thus reduce incentives to take risks). In contrast, Heider et 
al. (2018) find the opposite evidence in the Euro Area. For the authors, in the presence of negative rates, banks with more deposits finance riskier companies.

The determinants of banks' risk-taking react similarly to previous studies. The coefficients associated with banks' specific and country's specific controls are consistent with the results of the banking literature. These results are reported in Table E in the Appendix.

\subsection{The issue of bank heterogeneity}

Our previous results indicate that negative rates have had an impact on banks' margins and risk-taking. During the period of negative interest rate implementation, banks experienced a reduction in margins and took less risk. Moreover, having a heterogeneous database at both country and bank level, it is interesting to take advantage of this heterogeneity in order to better detail our results.

On the countries' side, heterogeneity is related to interest rates (fixed or variable) on loans to households and non-financial corporations. Indeed, depending on the interest rate applied to the credit, the effects of negative rates may be different. Moreover, IMF (2016) indicates that the effects of negative rates have been greater in countries with variable rates in the majority. Our previous results confirm those of the IMF (2016) insofar as our database is mainly composed of countries that mainly apply variable rates on credit ${ }^{34}$. On the banks' side, this heterogeneity is related to the size and quantity of liquid assets held by the banks in our sample. Indeed, depending on the size (small or large) and the holding of liquid assets (low or high), the effects of negative rates on banks may vary. Bottero et al. (2019) showed that negative rates had a greater impact on banks that held more liquidity than smaller banks. In the same vein as Bottero et al. (2019), we divided our sample between size and liquidity around the median of the distribution of the natural logarithm of total assets and the liquid asset ratio, respectively. If the size (or liquidity) of the bank is below the median, the bank is considered small (low) and conversely it is large (high). Size results are reported in Tables G and $\mathrm{H}$ and liquidity results in Tables I and $\mathrm{J}$.

These results show that the reduction of the interest rate by one percentage point have led to a reduction in banks' margins of $0.37 \%$ for small banks and $0.92 \%$ for large banks. Similarly, during the period of negative interest rate implementation, the reduction in banks' margins was greater among large banks and they would have taken less risk. In addition, the 1\% interest rate reduction reduces banks' margins by $0.47 \%$ for banks with few liquid assets and $0.37 \%$ for banks with more liquid assets. We also show that during negative interest rates, banks with few liquid assets reduced their profit before tax while those with more liquid assets increased it.

\subsection{Sensibility analyses}

In order to check the robustness of our results, we perform five sensitivity analyses. Firstly, one potential concern with this set-up is how monetary policy is measured at the annual

\footnotetext{
34 In our sample of countries, Belgium and France are the only countries whose share of fixed-rate loans to households and businesses is more than $50 \%$ compared to variable-rate loans.
} 
frequency (the average of all observations). We test the robustness of such an assumption by replacing the average of the observations with the value at December 31 of each year (the last observation of $i$ ). Table $\mathrm{K}$ reports results for banks' profitability and risk-taking, when we replace the average of all observations of the policy interest rate with the last annual observation. The coefficients associated with our main variables are qualitatively similar and leave our conclusions on both bank profitability and risk-taking virtually unchanged.

Secondly, in our sample Germany is the country with the most banks (916/2442). We decide to remove Germany from our sample to test if our baseline results are driven by German banks. After removing Germany, we find similar results (Table L). As a further robustness check, the United Kingdom's financial and banking system is not necessarily representative of the entire European Union, so we decided to remove the United Kingdom (UK) from our sample. We re-estimate equation (2), (3) and (4) after excluding the UK. The findings of this exercise are reported in Table M.

As a fourth robustness check, we have modified our sample of countries to keep only those countries where negative rates have been implemented (Bulgaria, Denmark, Euro Area countries, Hungary and Sweden). These results are reported in Table N, and are in line with those of the benchmark models. Finally, we replace the monetary policy rate with the overnight rate on the interbank market (inter).Indeed, the rate at which banks lend to each other is between the rate on deposit facilities (the floor) and the rate on marginal lending facilities (the ceiling). Changes in the deposit facility rate should then influence the interbank rate. For example, for the Euro Area we use the Eonia ${ }^{35}$ rate (Euro OverNight Index Average) which has also fallen below zero after the implementation of negative rates by the ECB. We find similar results for both the NIM and the z-score, reported in Table O.

\subsection{Negative interest rates, bank profitability and risk-taking}

In the previous sub-sections (5.1 and 5.2), we analyzed the effects of negative rates on both bank profitability and risk-taking. We note that negative rates have reduced both banks' net interest margins and their risk-taking. In compliance with traditional theory 36 , the reduction in profitability (measured by NIM) due to negative rates should encourage banks to take more risk. Thus, in this subsection, we verify this statement by looking at whether the reduction in NIM related to negative interest rates would have an impact on banks' risktaking ${ }^{37}$. To do this, using the equation (2) we determine the fitted values of NIM. The fitted values of NIM are then introduced into a new equation (4) on risk-taking.

$$
\operatorname{Risk}_{i, k, t}=c+\beta_{0} \operatorname{Risk}_{i, k, t-1}+\beta_{1} N \widehat{I M_{l, k, t}}+\beta_{2} X_{i, k, t-1}+\beta_{3} Y_{k, t}+\theta_{t}+\lambda_{k}+\varepsilon_{i, k, t}(5)
$$

Where $\operatorname{Risk}_{i, k, t}$ is the risk measures for bank $i$ in the country $k$ at time $t . N \widehat{I M_{\imath, k, t}}$ is the predicted values of banks' net interest margins by negative interest rates for bank $i$ in the

\footnotetext{
35 It results from the weighted average of the interest rates on all overnight transactions of loans denominated in euro that are not guaranteed and carried out by European banks.

36 The most profitable banks are those that take the least risk (see i.e., Jensen and Meckling, 1976; Keeley, 1990).

37 We recognize that the relationship between banks' profitability and risk-taking is much more complicated and is not a one-way route. Nevertheless, in this subsection we use it in this sense mainly to illustrate our previous results.
} 
country $k$ at time $t$. Using System GMM, we use this variable to determine the effects of profitability on banks' risk-taking in a negative interest rate environment.

The results of equation (5) are reported in Table 338 and we use the same measures of risktaking as in equation (4). We find that net interest margins related to negative interest rates are positively correlated with banks'risk-taking. Indeed, we show that in the presence of negative rates, the reduction of NIM would imply a reduction in banks' risk-taking. A $1 \%$ decrease in NIM (due to negative interest rate) favors a $5.44 \%$ decrease in non-performing loans on the balance sheet of European banks and increases the z-score by $1.78 \%$. Consequently, despite the negative effect of interest rates on NIM, European banks would have taken less risk. This result is consistent with Martynova et al. (2015) who show that more profitable banks may have higher risk-taking incentives. However, this result is opposed to the traditional theory that the more profitable the bank, the less risk it takes (see i.e., Jensen and Meckling, 1976; Keeley, 1990; Demsetz et al. 1996; Repullo, 2004). One of the explanations for the reduction in banks' risk-taking despite a negative shock on net interest margins is related to the fact that banks are highly regulated after the financial crisis (i.e., Basel III leverage ratio). Indeed, the objective of banking regulation is to strengthen the resilience of institutions and the banking system by allowing them to absorb the negative shocks associated with an unfavorable evolution of the economic cycle and the business climate.

\section{Conclusion}

Since 2012, six central banks in Europe and Bank of Japan have implemented negative rates, which aimed at stimulating economic growth by avoiding deflationary risk and domestic currency appreciation. This unconventional monetary policy tool is still at the heart of the political and academic debate regarding its potential effects on banks' profitability and risktaking.

In this paper, we have analyzed the effects of negative rates, introduced by European central banks, on both bank profitability and risk-taking. These relationships are analyzed for 2442 banks operating in the 28 countries of the European Union using a large set of panel data composed of interest rate variables, banks' specific variables and country's specific variables. Our empirical approach is based on a dynamic panel framework (System GMM) that take into account the persistent character of both profitability and risk-taking and overcome potential endogeneity problems that may arise in our estimates.

This article provides strong evidence of the presence of a threshold effect when rates are negative. Our empirical analysis shows that negative rates have reduced banks' margins. We show that negative interest rates have a significantly greater impact on margins than positive rates. This result then confirms the presumption that negative rates deteriorate banks' interest margins. Therefore, there is a threshold effect when interest rates become negative. Thus, in order to offset the effects on margins, banks increased their non-interest income (fees and commissions). As a result, during the implementation period of negative rates, they

\footnotetext{
38 The results for banks-specific and country-specific controls are presented in Table F.
} 
took less risk, in particular by reducing the share of non-performing loans. Moreover, despite a reduction in interest margins due to negative rates, banks were not encouraged to take more risk. We also find that the effects of negative rates on banks vary according to their characteristics.

These results hold and resist the inclusion of several bank and country-specific control variables. These results are also robust to a wide range of sensitivity analyses (including monitoring the effects of interbank rates and sub-sample analysis). However, the results of our estimates have some limitations. First, we study the effects of negative rates on excess reserves in terms of profitability and risk-taking by banks. Nevertheless, in order to have a more detailed analysis it would have been more efficient to use the amount of excess reserves as a proxy for negative rates. Because banks that do not hold excess reserves at the central bank are not very sensitive to negative rates. In fact, in a July 2016 report on the Euro Area the IMF indicated that banks holding excess reserves would bear a disproportionately higher cost due to negative interest rates. Second, our results do not allow us to state whether the reduction in risk-taking (measured by NPLs) during negative interest rates is linked to (i) NPLs contracted before the implementation of negative rates and maturing during the rates negative; or (ii) NPLs that have become efficient thanks to negative rates through a general equilibrium feedback mechanism for all unconventional monetary policies (improving the income and solvency of agents, etc.).

Overall, our findings contribute to the recent literature by showing that negative rates compress banks' margins and also contribute to improving financial stability. These results reiterate, for monetary and prudential authorities, the importance of taking financial stability into account in the design of various policies. 
Table 1 - The effects of negative interest rate policy on European banks' profitability

\begin{tabular}{|c|c|c|c|c|c|c|c|c|c|c|c|c|}
\hline & \multicolumn{4}{|c|}{ NIM } & \multicolumn{4}{|c|}{ PROBTA } & \multicolumn{4}{|c|}{ ROA } \\
\hline & OLS & S-GMM & S-GMM & S-GMM & OLS & S-GMM & S-GMM & S-GMM & OLS & S-GMM & S-GMM & S-GMM \\
\hline \multirow[t]{2}{*}{ i } & $0.122^{* * *}$ & $0.429^{* * *}$ & & $0.420^{\star * *}$ & $-0.026^{*}$ & -0.07 & & -0.945 & $-0.137^{* * *}$ & * -0.136 & & $1.696^{*}$ \\
\hline & [0.03] & [0.13] & & [0.16] & {$[0.01]$} & {$[0.20]$} & & [0.71] & {$[0.06]$} & {$[0.21]$} & & {$[0.88]$} \\
\hline \multirow[t]{2}{*}{$\mathrm{D}_{\mathrm{NIRP}}$} & & & $-2.097^{* * *}$ & $* 0.582^{* * *}$ & & & 0.033 & 0.279 & & & 0.061 & 0.348 \\
\hline & & & {$[0.60]$} & {$[0.22]$} & & & [0.14] & [0.26] & & & [0.53] & [0.39] \\
\hline \multirow[t]{2}{*}{$\mathrm{i} * \mathrm{D}_{\mathrm{NIRP}}$} & & & & $0.603^{* * *}$ & & & & $2.508^{* * *}$ & & & & $-1.60^{*}$ \\
\hline & & & & [0.22] & & & & [1.06] & & & & {$[0.94]$} \\
\hline \multirow[t]{2}{*}{$\mathrm{Z}_{\mathrm{t}-1}$} & $0.958^{* * *}$ & $0.705^{* * *}$ & 0.172 & $0.828^{* * *}$ & $0.655^{* * *}$ & 0.163 & $0.942^{* * *}$ & 0.348 & $0.406^{* * *}$ & $0.701^{* * *}$ & $0.883^{* * *}$ & $0.690^{* * *}$ \\
\hline & {$[0.01]$} & [0.18] & {$[0.13]$} & [0.11] & [0.02] & [0.28] & [0.22] & [0.23] & {$[0.06]$} & {$[0.25]$} & [0.33] & {$[0.17]$} \\
\hline$X_{i, k, t}$ & Yes & Yes & Yes & Yes & Yes & Yes & Yes & Yes & Yes & Yes & Yes & Yes \\
\hline$Y_{k, t}$ & Yes & Yes & Yes & Yes & Yes & Yes & Yes & Yes & Yes & Yes & Yes & Yes \\
\hline Obs. & 4750 & 4750 & 4750 & 4750 & 4750 & 4750 & 4750 & 4750 & 4750 & 4750 & 4750 & 4750 \\
\hline Banks & 2442 & 2442 & 2442 & 2442 & 2442 & 2442 & 2442 & 2442 & 2442 & 2442 & 2442 & 2442 \\
\hline Instr. & & 29 & 17 & 19 & & 20 & 17 & 21 & & 25 & 16 & 29 \\
\hline $\mathrm{R}^{2}$ & 0.17 & & & & 0.02 & & & & 0.03 & & & \\
\hline $\mathrm{AR}(1)$ & & -2.87 & -2.03 & -3.12 & & -3.12 & -4.26 & -2.34 & & -2.86 & -4.48 & -3.30 \\
\hline $\mathrm{AR}(2)$ & & -0.14 & -0.27 & -0.01 & & 1.01 & 1.64 & 1.42 & & 0.77 & 0.43 & 0.76 \\
\hline Hansen & & 0.11 & 0.64 & 0.51 & & 0.03 & 0.51 & 0.11 & & 0.67 & 0.14 & 0.42 \\
\hline
\end{tabular}

Notes: The sample comprises annual data of 2442 European banks operating in 28 countries from European Union over the period 2011-2017. The estimations are based on OLS estimator and the Arellano and Bond (1991) System GMM estimator (or two-step dynamic panel estimation). $X_{i, k, t}$ and $Y_{k, t}$ are banks'specific and country'specific controls. The t-statistics based on Windmeijer (2005) correction of variance is reported in parentheses. ${ }^{* * *}$, ${ }^{* *}$ and * are statistical significances at 0.01, 0.05 and 0.10 level, respectively. AR (1) and AR (2) are the test for first and second-order autocorrelation and Hansen is the $\mathrm{p}$-value of the Hansen test for over-identifying restrictions. The command "collapse" is used to limit the number of instruments. Table A gives the definitions of the variables. 
Table 2 - The effects of negative interest rate policy on European banks' risk-taking

\begin{tabular}{|c|c|c|c|c|c|c|c|c|c|c|c|c|}
\hline & \multicolumn{4}{|c|}{ NPLs } & \multicolumn{4}{|c|}{ Provisions } & \multicolumn{4}{|c|}{ Z-score } \\
\hline & OLS & S-GMM & S-GMM & S-GMM & OLS & S-GMM & S-GMM & S-GMM & OLS & S-GMM & S-GMM & S-GMM \\
\hline \multirow[t]{2}{*}{$\mathrm{i}$} & $0.302^{* * *}$ & $2.358^{* * *}$ & & $-1.733^{* *}$ & $0.239 * * *$ & $0.978^{* * *}$ & & -0.425 & $-0.209^{* * *}$ & $-0.746^{* *}$ & & $0.472^{* *}$ \\
\hline & {$[0.11]$} & [0.77] & & {$[0.80]$} & {$[0.02]$} & {$[0.26]$} & & [1.89] & {$[0.04]$} & [0.37] & & [0.22] \\
\hline \multirow[t]{2}{*}{$\mathrm{D}_{\mathrm{NIRP}}$} & & & $-2.833^{* * *}$ & $-3.213^{* *}$ & & & $-1.016^{*}$ & -0.716 & & & $0.663^{*}$ & $0.872^{* * *}$ \\
\hline & & & [1.00] & [1.34] & & & [0.53] & [0.47] & & & [0.37] & [0.31] \\
\hline \multirow[t]{2}{*}{$\mathrm{i} * \mathrm{D}_{\mathrm{NIRP}}$} & & & & $1.245^{*}$ & & & & 1.879 & & & & -0.257 \\
\hline & & & & {$[0.74]$} & & & & [2.51] & & & & [0.23] \\
\hline \multirow[t]{2}{*}{$Z_{t-1}$} & $0.922^{* * *}$ & $0.932^{* * *}$ & $0.936^{* * *}$ & $0.880^{* * *}$ & $0.627^{* * *}$ & $0.979 * * *$ & $0.726^{* * *}$ & -0.412 & $0.744^{* * *}$ & $0.553^{* * *}$ & $0.554^{* * *}$ & $0.949^{* * *}$ \\
\hline & {$[0.01]$} & {$[0.07]$} & {$[0.04]$} & {$[0.04]$} & {$[0.02]$} & {$[0.18]$} & {$[0.25]$} & [0.52] & {$[0.01]$} & {$[0.07]$} & {$[0.07]$} & {$[0.13]$} \\
\hline$X_{i, k, t}$ & Yes & Yes & Yes & Yes & Yes & Yes & Yes & Yes & Yes & Yes & Yes & Yes \\
\hline$Y_{k, t}$ & Yes & Yes & Yes & Yes & Yes & Yes & Yes & Yes & Yes & Yes & Yes & Yes \\
\hline Obs. & 4750 & 4750 & 4750 & 4750 & 4750 & 4750 & 4750 & 4750 & 4750 & 4750 & 4750 & 4750 \\
\hline Banks & 2442 & 2442 & 2442 & 2442 & 2442 & 2442 & 2442 & 2442 & 2442 & 2442 & 2442 & 2442 \\
\hline Instr. & & 20 & 17 & 19 & & 17 & 18 & 18 & & 17 & 24 & 33 \\
\hline $\mathrm{R}^{2}$ & 0.14 & & & & 0.04 & & & & 0.02 & & & \\
\hline $\mathrm{AR}(1)$ & & -4.69 & -5.31 & -5.37 & & -4.67 & -3.43 & -1.29 & & -6.79 & -6.58 & -5.78 \\
\hline $\mathrm{AR}(2)$ & & -1.67 & -1.55 & -1.33 & & -0.72 & -0.67 & -1.72 & & -1.46 & -1.65 & -0.97 \\
\hline Hansen & & 0.14 & 0.11 & 0.60 & & 0.06 & 0.20 & 0.06 & & 0.84 & 0.13 & 0.19 \\
\hline
\end{tabular}

Notes: The sample comprises annual data of 2442 European banks operating in 28 countries from European Union over the period 2011-2017. The estimations are based on OLS estimator and the Arellano and Bond (1991) System GMM estimator (or two-step dynamic panel estimation). $X_{i, k, t}$ and $Y_{k, t}$ are banks'specific and country'specific controls. The t-statistics based on Windmeijer (2005) correction of variance is reported in parentheses. ${ }^{* * *},{ }^{* *}$ and * are statistical significances at 0.01, 0.05 and 0.10 level, respectively. AR (1) and AR (2) are the test for first and second-order autocorrelation and Hansen is the p-value of the Hansen test for overidentifying restrictions. The command "collapse" is used to limit the number of instruments. Table A gives the definitions of the variables. 
Table 3 - The effects of bank profitability on risk-taking

\begin{tabular}{c|cc|cc|cc}
\hline \hline & \multicolumn{2}{|c|}{ NPLs } & \multicolumn{2}{c|}{ Provisions } & \multicolumn{2}{c}{ Z-score } \\
& OLS & S-GMM & OLS & S-GMM & OLS & S-GMM \\
\hline$N \widehat{I M_{i, k, t}}$ & $0.791^{* * *}$ & $5.436^{* *}$ & $0.559^{* * *}$ & 0.749 & $-0.520^{* * *}$ & $-1.775^{* *}$ \\
Risk $_{\mathrm{t}-1}$ & {$[0.26]$} & {$[2.41]$} & {$[0.06]$} & {$[1.11]$} & {$[0.11]$} & {$[0.88]$} \\
& $0.921^{* * *}$ & $0.799^{* * *}$ & $0.632^{* * *}$ & $0.413^{* *}$ & $0.750^{* * *}$ & $0.553^{* * *}$ \\
& {$[0.01]$} & {$[0.08]$} & {$[0.01]$} & {$[0.19]$} & {$[0.01]$} & {$[0.07]$} \\
\hline $\mathrm{X}_{\mathrm{i}, \mathrm{k}, \mathrm{t}}$ & Yes & Yes & Yes & Yes & Yes & Yes \\
$\mathrm{Y}_{\mathrm{k}, \mathrm{t}}$ & Yes & Yes & Yes & Yes & Yes & Yes \\
Obs. & 4750 & 4750 & 4750 & 4750 & 4750 & 4750 \\
Banks & 2442 & 2442 & 2442 & 2442 & 2442 & 2442 \\
Instr. & & 16 & & 17 & & 17 \\
$\mathrm{R}^{2}$ & 0.15 & & 0.03 & & 0.02 & \\
\hline AR(1) & & -5.08 & & -3.55 & & -6.79 \\
AR(2) & & -1.27 & & -1.09 & & -1.46 \\
Hansen & & 0.83 & & 0.84 & & 0.84 \\
\hline Notes:
\end{tabular}

Notes: The sample comprises annual data of 2442 European banks operating in 28 countries from European Union over the period 2011-2017. The estimations are based on OLS estimator and the Arellano and Bond (1991) System GMM estimator (or two-step dynamic panel estimation). $X_{i, k, t}$ and $\mathrm{Y}_{\mathrm{k}, \mathrm{t}}$ are banks'specific and country'specific controls. The $\mathrm{t}-$ statistics based on Windmeijer (2005) correction of variance is reported in parentheses. ***, ** and * are statistical significances at 0.01, 0.05 and 0.10 level, respectively. AR (1) and AR (2) are the test for first and second-order autocorrelation and Hansen is the p-value of the Hansen test for over-identifying restrictions. The command "collapse" is used to limit the number of instruments. Table A gives the definitions of the variables. 


\section{Figure 1 - Main policy rates}

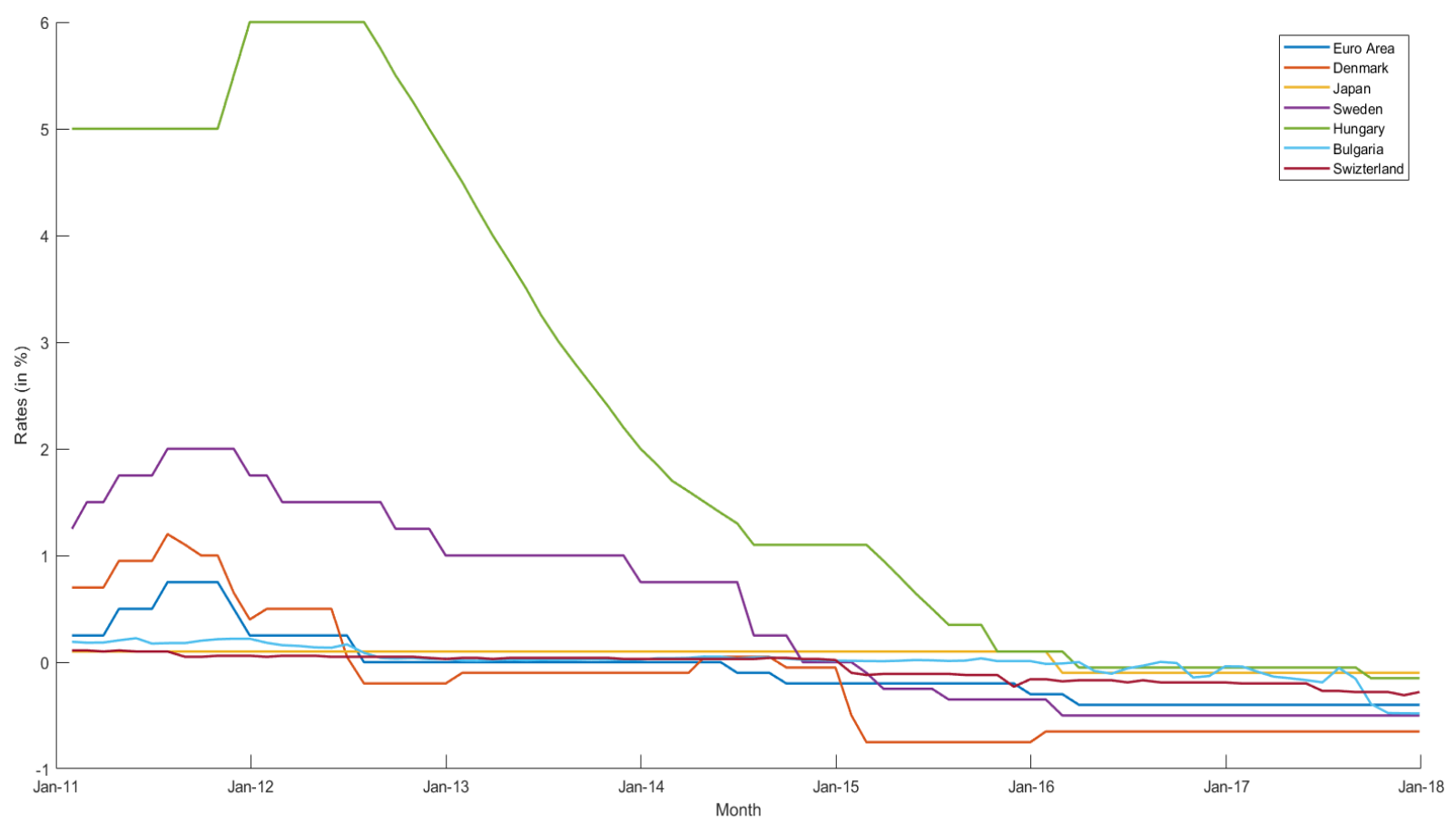

Notes :The evolution between Jan-2011 and Dec-2017 of the monetary policy rate, which has turned negative. Euro Area (Deposit facility rate), Denmark (Certificates of deposit rate), Sweden (Deposit rate), Switzerland (3month Libor targer rate), Japan (Uncollateralized overnight rate), Hungary (Deposit rate) and Bulgaria (Deposit rate). 


\section{APPENDIX}

Table A - Descriptive statistics

\begin{tabular}{|c|c|c|c|c|c|c|c|}
\hline Variable & Description & Obs. & Mean & SD & Min & $\operatorname{Max}$ & Source \\
\hline \multicolumn{8}{|c|}{ Profitability measures } \\
\hline Net interest margin & $\begin{array}{c}\text { Net interest revenue to total } \\
\text { earning assets }\end{array}$ & 7798 & 2.23 & 2.52 & -6.26 & 54.36 & Orbis Bank Focus \\
\hline Return on assets & Net income to total assets & 7798 & 0.41 & 1.21 & -24.17 & 30.26 & Orbis Bank Focus \\
\hline PROBTA & Profit before tax to total assets & 7798 & 0.61 & 0.44 & 0.03 & 1.49 & Orbis Bank Focus \\
\hline \multicolumn{8}{|c|}{ Risk-taking measures } \\
\hline Z-score & $\begin{array}{l}\text { The natural logarithm of Z- } \\
\text { score }\end{array}$ & 7798 & 4.62 & 1.38 & 2.38 & 6.73 & $\begin{array}{l}\text { Orbis Bank Focus and } \\
\text { Author's computation }\end{array}$ \\
\hline NPLs & $\begin{array}{c}\text { Impaired loans (NPLs) to gross } \\
\text { loans }\end{array}$ & 7798 & 6.39 & 6.28 & 0.55 & 19.56 & Orbis Bank Focus \\
\hline Provisions & $\begin{array}{c}\text { Loans loss provisions to gross } \\
\text { loans }\end{array}$ & 7798 & 0.52 & 0.69 & 0.2 & 1.97 & Orbis Bank Focus \\
\hline \multicolumn{8}{|c|}{ Monetary policy measures } \\
\hline $\mathrm{i}$ & $\begin{array}{c}\text { Main policy rate which became } \\
\text { negative }\end{array}$ & 7798 & -0.27 & 0.31 & -1.25 & 2.41 & Central banks \\
\hline $\mathrm{D}_{\mathrm{NIRP}}$ & $\begin{array}{l}\text { Negative interest rate policy } \\
\text { (dummy) }\end{array}$ & 7798 & 0.8 & 0.4 & 0 & 1 & Author's computation \\
\hline $\mathrm{i}^{*} \mathrm{D}_{\mathrm{NIRP}}$ & Interaction variable & 7798 & -0.3 & 0.23 & -1.25 & 0 & $\begin{array}{l}\text { Central banks and } \\
\text { Author's computation }\end{array}$ \\
\hline \multicolumn{8}{|c|}{ Bank-specific controls $X_{t}$} \\
\hline Size & $\begin{array}{l}\text { The natural logarithm of total } \\
\text { assets }\end{array}$ & 7798 & 7.9 & 1.99 & 4.44 & 14.8 & Orbis Bank Focus \\
\hline Equity & Equity to total assets ratio & 7798 & 9.48 & 3.08 & 5.106 & 15.14 & Orbis Bank Focus \\
\hline Liquidity & $\begin{array}{l}\text { Liquid assets to total assets } \\
\text { ratio }\end{array}$ & 7798 & 14.23 & 10.46 & 3.47 & 36 & Orbis Bank Focus \\
\hline Efficiency & Cost to income ratio & 7798 & 69.79 & 15.45 & 44.66 & 92.62 & Orbis Bank Focus \\
\hline \multicolumn{8}{|c|}{ Country-specific controls $Y_{t}$} \\
\hline HHI & Herfindahl-Hirschman index & 7798 & 838.2 & 420.12 & 430.75 & 3031.81 & $\begin{array}{l}\text { Orbis Bank Focus and } \\
\text { Author's computation }\end{array}$ \\
\hline GDP & Real GDP growth rate & 7764 & 1.19 & 1.09 & -5.93 & 8.17 & $\begin{array}{l}\text { Datastream and } \\
\text { World Bank }\end{array}$ \\
\hline Inflation & $\begin{array}{l}\text { Consumer price index annual } \\
\text { growth rate }\end{array}$ & 7676 & 0.53 & 0.7 & -2.1 & 4.01 & Datastream \\
\hline Spread & $\begin{array}{c}\text { Yield curve slope }(10 \mathrm{y}-3 \mathrm{~m} \\
\text { interbank rate) }\end{array}$ & 7686 & 1.23 & 1.11 & -2.23 & 9.8 & Datastream, OCDE \\
\hline
\end{tabular}

Notes: The table reports summary statistics for the variables used in the empirical analysis. Data are at annual frequency covering the period 2011-2017. Z-score $=($ ROA + Equity/Assets $) /$ o_ROA; o_ROA is the standard deviation of ROA. In the calculation of z-score, we use, as Beck et al. (2013), a three-year rolling time window to compute the standard deviation of ROA rather than the full sample period. $D_{\text {NIRP }}$ takes the value 1 when NIRP from the year of implementation of the negative rates and following and the value 0 before this period. 
Table B - Central Banks that have implemented negative policy rate

\begin{tabular}{|c|c|c|c|c|}
\hline $\begin{array}{l}\text { Country / } \\
\text { Zone }\end{array}$ & Central bank & $\begin{array}{c}\text { Policy interest } \\
\text { rate }\end{array}$ & Date & Rate \\
\hline \multirow{9}{*}{ Denmark } & \multirow{9}{*}{ DanmarksNationalBank } & \multirow{9}{*}{$\begin{array}{c}\text { Certificates of } \\
\text { deposit rate }\end{array}$} & July 6, 2012 & $-0.20 \%$ \\
\hline & & & January 25, 2013 & $-0.10 \%$ \\
\hline & & & April 25, 2014 & $+0.05 \%$ \\
\hline & & & September 5, 2014 & $-0.05 \%$ \\
\hline & & & January 19, 2015 & $-0.20 \%$ \\
\hline & & & January 22, 2015 & $-0.35 \%$ \\
\hline & & & January 29, 2015 & $-0.50 \%$ \\
\hline & & & February 5, 2015 & $-0.75 \%$ \\
\hline & & & January 8, 2016 & $-0.65 \%$ \\
\hline \multirow{5}{*}{ Euro Area } & \multirow{5}{*}{ European Central Bank } & \multirow{5}{*}{$\begin{array}{l}\text { Deposit facility } \\
\text { rate }\end{array}$} & June 11, 2014 & $-0.10 \%$ \\
\hline & & & September 10, & $-0.20 \%$ \\
\hline & & & 2014 & $-0.30 \%$ \\
\hline & & & December 9, 2015 & $-0.40 \%$ \\
\hline & & & March 16, 2016 & \\
\hline \multirow{5}{*}{ Sweden } & \multirow{5}{*}{ SverigesRiksbank } & \multirow{5}{*}{ Deposit rate } & July9, 2014 & $-0.50 \%$ \\
\hline & & & February18, 2015 & $-0.85 \%$ \\
\hline & & & March 25, 2015 & $-1.00 \%$ \\
\hline & & & July8, 2015 & $-1.10 \%$ \\
\hline & & & February 17, 2016 & $-1.25 \%$ \\
\hline \multirow{3}{*}{ Hungary } & \multirow{3}{*}{ Magyar Nemzeti Bank } & \multirow{3}{*}{ Deposit rate } & March 23, 2016 & $-0.05 \%$ \\
\hline & & & & \\
\hline & & & $\begin{array}{c}\text { September 20, } \\
2017\end{array}$ & $-0.15 \%$ \\
\hline \multirow[b]{2}{*}{ Bulgaria } & \multirow[b]{2}{*}{$\begin{array}{l}\text { Bulgarian National } \\
\text { Bank }\end{array}$} & \multirow[b]{2}{*}{ Deposit rate } & January 4, 2016 & $-0.30 \%$ \\
\hline & & & March 16, 2016 & $-0.40 \%$ \\
\hline
\end{tabular}

Source: Central banks 
Table C - The number of banks per country in our sample

\begin{tabular}{|c|c|c|}
\hline Country & \# of banks & Central bank \\
\hline Austria & 42 & European Central Bank (ECB) \\
\hline Belgium & 20 & ECB \\
\hline Bulgaria & 20 & Bulgarian National Bank \\
\hline Croatia & 27 & HrvatskaNarodna Banka \\
\hline Cyprus & 25 & ECB \\
\hline Czech Republic & 26 & Czech National Bank \\
\hline Denmark & 60 & DanmarksNationalBank \\
\hline Estonia & 8 & ECB \\
\hline Finland & 43 & ECB \\
\hline France & 265 & ECB \\
\hline Germany & 916 & ECB \\
\hline Greece & 10 & ECB \\
\hline Hungary & 15 & Magyar Nemzeti Bank \\
\hline Ireland & 13 & ECB \\
\hline Italy & 391 & ECB \\
\hline Latvia & 11 & ECB \\
\hline Lithuania & 6 & ECB \\
\hline Luxembourg & 24 & ECB \\
\hline Malta & 10 & ECB \\
\hline Netherlands & 33 & ECB \\
\hline Poland & 29 & Narodowy Bank Polski \\
\hline Portugal & 80 & ECB \\
\hline Romania & 23 & Banca National A Romaniei \\
\hline Slovakia & 14 & ECB \\
\hline Slovenia & 12 & ECB \\
\hline Spain & 65 & ECB \\
\hline Sweden & 89 & SverigesRiksbank \\
\hline United Kingdom & 165 & Bank of England \\
\hline Total & 2442 & \\
\hline
\end{tabular}


Table D - The effects of negative interest rate policy on European banks' profitability

\begin{tabular}{|c|c|c|c|c|c|c|c|c|c|c|c|c|}
\hline & \multicolumn{4}{|c|}{ NIM } & \multicolumn{4}{|c|}{ PROBTA } & \multicolumn{4}{|c|}{$\overline{\mathrm{ROA}}$} \\
\hline & OLS & S-GMM & S-GN & S-GMM & OLS & S-GMM & S-GN & I S-GMM & OLS & S-GMM & & \\
\hline \multirow[t]{2}{*}{$i$} & $0.122^{* * *}$ & $0.429^{* * *}$ & & $0.420 * * *$ & $-0.026^{*}$ & -0.07 & & -0.945 & $-0.137^{* * *}$ & * -0.136 & & $1.696^{*}$ \\
\hline & 3] & & & {$[0.16]$} & [0.01] & [0.20] & & {$[0.71]$} & [0.06] & [0.21] & & {$[0.88]$} \\
\hline \multirow[t]{2}{*}{$\mathrm{D}_{\mathrm{NIRP}}$} & & & $-2.097^{* * *}$ & $* 0.582^{* * *}$ & & & 0.033 & 0.279 & & & 0.061 & 0.348 \\
\hline & & & {$[0.60]$} & [0.22] & & & {$[0.14]$} & {$[0.26]$} & & & [0.53] & [0.39] \\
\hline \multirow{2}{*}{$\mathrm{i} * \mathrm{D}_{\mathrm{NIRP}}$} & & & & $0.603^{* * *}$ & & & & $2.508^{* * *}$ & & & & $-1.60^{*}$ \\
\hline & & & & {$[0.22]$} & & & & {$[1.06]$} & & & & {$[0.94]$} \\
\hline \multirow[t]{2}{*}{$\mathrm{Z}_{\mathrm{t}-1}$} & $0.958^{* * *}$ & $0.705^{\star * *}$ & 0.172 & $0.828^{* * *}$ & $0.655^{* * *}$ & 0.163 & $0.942^{* * *}$ & 0.348 & $0.406^{* * *}$ & $0.701^{* * *}$ & $0.883^{* * *}$ & $0.690^{* * *}$ \\
\hline & [0.01] & [0.18] & [0.13] & [0.11] & [0.02] & [0.28] & {$[0.22]$} & {$[0.23]$} & [0.06] & {$[0.25]$} & [0.33] & [0.17] \\
\hline \multirow{2}{*}{ Liquidity } & $-0.002^{* * *}$ & 0 & 0.006 & 0 & $0.001^{* * *}$ & 0.006 & 07 & 0.002 & $0.002^{* *}$ & 0.003 & 0.022 & $0.226^{*}$ \\
\hline & [0.00] & {$[0.00]$} & {$[0.01]$} & [0.01] & {$[0.00]$} & [0.00] & {$[0.00]$} & {$[0.00]$} & [0.00] & [0.01] & [0.03] & {$[0.01]$} \\
\hline \multirow[t]{2}{*}{ Equity } & 0.002 & 0.007 & $0.101^{*}$ & -0.022 & $0.019^{* * *}$ & 0.025 & -0.02 & -0.017 & $0.059 * * *$ & -0.007 & -0.086 & -0.023 \\
\hline & [0.00] & {$[0.04]$} & {$[0.05]$} & [0.04] & [0.00] & [0.03] & {$[0.02]$} & {$[0.04]$} & {$[0.00]$} & [0.06] & {$[0.10]$} & {$[0.07]$} \\
\hline \multirow[t]{2}{*}{ Efficiency } & $-0.001^{* * *}$ & $0.001^{*}$ & 0.001 & $0.001^{* *}$ & $-0.003^{* * *}$ & $-0.109^{* * *}$ & 0.003 & 0.001 & $-0.011^{* * *}$ & * $\quad 0.007$ & $0.030^{* *}$ & -0.001 \\
\hline & {$[0.00]$} & {$[0.00]$} & {$[0.00]$} & {$[0.00]$} & {$[0.00]$} & [0.00] & & 0] & [0.00] & [0.01] & & {$[0.01]$} \\
\hline \multirow[t]{2}{*}{ Size } & 0.002 & -0.043 & $-0223^{* *}$ & $-0.236^{* * *}$ & $0.007^{* * *}$ & -0.027 & -0.01 & 0.051 & $0.017^{* *}$ & $0.116^{* *}$ & -0.007 & -0.04 \\
\hline & [0.00] & [0.03] & {$[0.10]$} & [0.07] & {$[0.00]$} & [0.02] & {$[0.03]$} & {$[0.04]$} & [0.01] & [0.05] & [0.10] & {$[0.06]$} \\
\hline \multirow[t]{2}{*}{ HHI } & 5.2E-06 & 6.3E-05 & 0.0002 & $-4 \mathrm{E}-05$ & 2.1E-05 & $-4 \mathrm{E}-05$ & 5E-05 & $3 \mathrm{E}-04^{* * *}$ & $-2 \mathrm{E}-05$ & $2 \mathrm{E}-04^{* *}$ & $3 \mathrm{E}-04^{*}$ & 7.6E-05 \\
\hline & {$[0.00]$} & {$[0.00]$} & {$[0.00]$} & {$[0.00]$} & [0.00] & {$[0.00]$} & {$[0.00]$} & [0.00] & {$[0.00]$} & {$[0.00]$} & {$[0$.} & {$[0.00]$} \\
\hline \multirow[t]{2}{*}{ Inflation } & 0.011 & -0.007 & $-0.096^{* * *}$ & $* 0.052^{* * *}$ & $0.027^{* * *}$ & 0.032 & 2 & -0.001 & $0.043^{* *}$ & -0.017 & 03 & 032 \\
\hline & [0.01] & [0.01] & {$[0.03]$} & [0.02] & {$[0.01]$} & [0.02] & {$[0.02]$} & {$[0.02]$} & [0.03] & [0.04] & & {$[0.03]$} \\
\hline \multirow[t]{2}{*}{ GDP } & $0.029^{* * *}$ & $0.054^{* * *}$ & -0.079 & $0.193^{* * *}$ & $0.017^{* * *}$ & 0.032 & 0.005 & $0.075^{*}$ & 0.001 & $-0.085^{* *}$ & -0.026 & -0.057 \\
\hline & [0.01] & {$[0.02]$} & [0.05] & [0.05] & {$[0.01]$} & [0.02] & {$[0.02]$} & {$[0.04]$} & [0.02] & [0.04] & {$[0.07]$} & {$[0.05]$} \\
\hline \multirow[t]{2}{*}{ Spread } & 0.015 & 0.002 & -0.016 & $0.054^{* *}$ & $-0.016^{* * *}$ & -0.019 & 0.027 & $-0.068^{*}$ & $-0.064^{* * *}$ & * -0.043 & 0.069 & -0.05 \\
\hline & [0.01] & [0.03] & {$[0.04]$} & & {$[0.00]$} & {$[0.02]$} & & {$[0.04]$} & [0.03] & [0.04] & & $0.04]$ \\
\hline \multirow[t]{2}{*}{ Constant } & 0.064 & $0.790^{*}$ & $4.30^{\star * *}$ & $1.855^{\star * *}$ & $0.142^{* * *}$ & $1.107^{*}$ & -0.127 & 0.059 & $0.332^{* * *}$ & $-1.399^{*}$ & -1.839 & 0.202 \\
\hline & {$[0.1]$} & {$[0.42]$} & {$[1.70]$} & {$[0.64]$} & {$[0.03]$} & {$[0.58]$} & {$[0.63]$} & {$[0.07]$} & {$[0.16]$} & [0.85] & & [1.29] \\
\hline Obs & 4750 & 4750 & 4750 & 4750 & 4750 & 4750 & 4750 & 4750 & 4750 & 4750 & 4750 & 4750 \\
\hline Banks & 2442 & 2442 & 2442 & 2442 & 2442 & 2442 & 2442 & 2442 & 2442 & 2442 & 2442 & 2442 \\
\hline Instr. & & 29 & 17 & 19 & & 20 & 17 & 21 & & 25 & 16 & 29 \\
\hline $\mathrm{R}^{2}$ & 0.17 & & & & 0.02 & & & & 0.03 & & & \\
\hline $\mathrm{AR}(1)$ & & -2.87 & -2.03 & -3.12 & & -3.12 & -4.26 & -2.34 & & -2.86 & -4.48 & -3.30 \\
\hline $\mathrm{AR}(2)$ & & -0.14 & -0.27 & -0.01 & & 1.01 & 1.64 & 1.42 & & 0.77 & 0.43 & 0.76 \\
\hline Hansen & & 0.11 & 0.64 & 0.51 & & 0.03 & 0.51 & 0.11 & & 0.67 & 0.14 & 0.42 \\
\hline
\end{tabular}

Notes: The sample comprises annual data of 2442 European banks operating in 28 countries from European Union over the period 2011-2017. The estimations are based on OLS estimator and the Arellano and Bond (1991) System GMM estimator (or two-step dynamic panel estimation). The t-statistics based on Windmeijer (2005) correction of variance is reported in parentheses. ***, ${ }^{* *}$ and * are statistical significances at $0.01,0.05$ and 0.10 level, respectively. AR (1) and AR (2) are the test for first and second-order autocorrelation and Hansen is the pvalue of the Hansen test for over-identifying restrictions. The command "collapse" is used to limit the number of instruments. Table A gives the definitions of the variables. 
Table E - The effects of negative interest rate policy on European banks' risk-taking

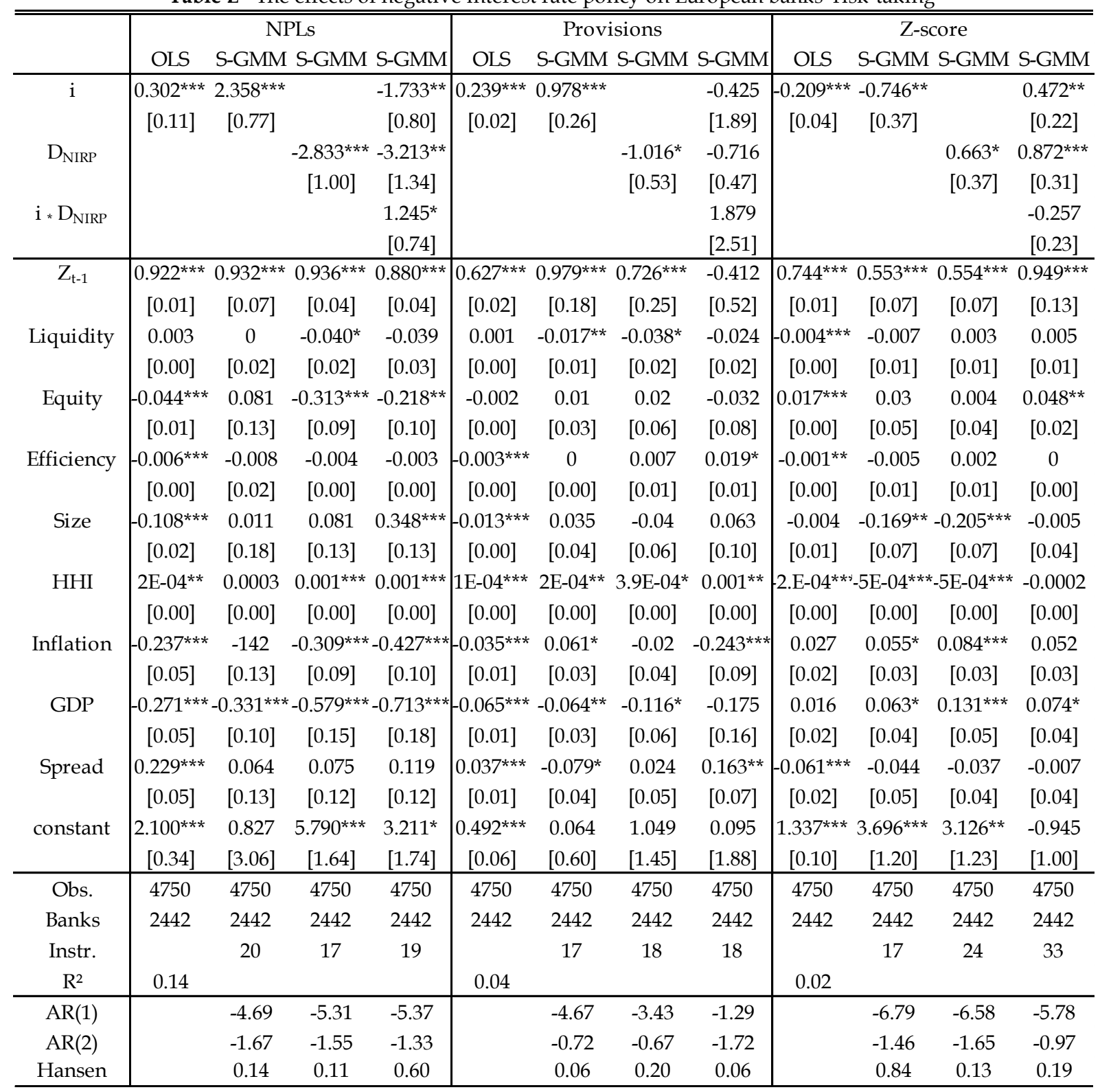

Notes: The sample comprises annual data of 2442 European banks operating in 28 countries from European Union over the period 2011-2017. The estimations are based on OLS estimator and the Arellano and Bond (1991) System GMM estimator (or two-step dynamic panel estimation). The t-statistics based on Windmeijer (2005) correction of variance is reported in parentheses. ${ }^{* * *},{ }^{* *}$ and * are statistical significances at $0.01,0.05$ and 0.10 level, respectively. AR (1) and AR (2) are the test for first and second-order autocorrelation and Hansen is the pvalue of the Hansen test for over-identifying restrictions. The command "collapse" is used to limit the number of instruments. Table A gives the definitions of the variables. 
Table F - The effects of bank profitability on risk-taking

\begin{tabular}{|c|c|c|c|c|c|c|}
\hline & \multicolumn{2}{|c|}{ NPLs } & \multicolumn{2}{|c|}{ Provisions } & \multicolumn{2}{|c|}{ Z-score } \\
\hline & OLS & S-GMM & OLS & S-GMM & OLS & S-GMM \\
\hline \multirow{2}{*}{$N \widehat{I M_{i, k}, t}$} & $0.791^{* * *}$ & $5.436^{* *}$ & $0.559^{* * *}$ & 0.749 & $-0.520^{* * *}$ & $-1.775^{* *}$ \\
\hline & {$[0.26]$} & [2.41] & [0.06] & [1.11] & [0.11] & [0.88] \\
\hline \multirow[t]{2}{*}{$\operatorname{Risk}_{\mathrm{t}-1}$} & $0.921^{* * *}$ & $0.799 * * *$ & $0.632^{* * *}$ & $0.413^{* *}$ & $0.750 * * *$ & $0.553^{* * *}$ \\
\hline & [0.01] & [0.08] & [0.01] & [0.19] & [0.01] & [0.07] \\
\hline \multirow[t]{2}{*}{ Liquidity } & 0 & 0.01 & 0 & $-0.012^{*}$ & $-0.003^{* * *}$ & -0.007 \\
\hline & {$[0.00]$} & {$[0.03]$} & [0.00] & {$[0.01]$} & [0.00] & {$[0.01]$} \\
\hline \multirow[t]{2}{*}{ Equity } & $-0.034^{* * *}$ & -0.117 & $0.008^{* * *}$ & 0.004 & 0.004 & 0.03 \\
\hline & {$[0.01]$} & [0.17] & [0.00] & {$[0.05]$} & {$[0.00]$} & [0.05] \\
\hline \multirow[t]{2}{*}{ Efficiency } & $-0.005^{* * *}$ & 0.007 & $-0.001^{* * *}$ & 0 & 0 & -0.005 \\
\hline & {$[0.00]$} & [0.02] & {$[0.00]$} & {$[0.00]$} & {$[0.00]$} & {$[0.01]$} \\
\hline \multirow[t]{2}{*}{ Size } & $-0.087^{* * *}$ & 0.17 & -0.002 & -0.035 & -0.008 & $-0.169^{* *}$ \\
\hline & [0.02] & [0.23] & {$[0.00]$} & {$[0.03]$} & {$[0.01]$} & [0.07] \\
\hline \multirow[t]{2}{*}{$\mathrm{HHI}$} & $3 \mathrm{E}-04^{* * *}$ & $0.001^{* *}$ & $1 \mathrm{E}-04^{* * *}$ & ${ }^{*} 2.4 \mathrm{E}-04^{*}$ & $-2 \mathrm{E}-04^{* * *}$ & ${ }^{*}-0.001^{* * *}$ \\
\hline & {$[0.00]$} & {$[0.00]$} & [0.00] & {$[0.00]$} & [0.00] & {$[0.00]$} \\
\hline \multirow[t]{2}{*}{ Inflation } & $-0.240^{* * *}$ & $-0.380^{* * *}$ & $-0.034^{* * *}$ & -0.048 & 0.022 & $0.055^{*}$ \\
\hline & {$[0.04]$} & [0.13] & [0.01] & [0.03] & [0.02] & [0.03] \\
\hline \multirow[t]{2}{*}{ GDP } & $-0.294^{* * *}$ & $-0.447^{* * *}$ & $-0.072^{* * *}$ & -0.058 & 0.022 & $0.063^{*}$ \\
\hline & [0.04] & [0.14] & [0.01] & {$[0.04]$} & {$[0.02]$} & {$[0.04]$} \\
\hline \multirow[t]{2}{*}{ Spread } & $0.231^{* * *}$ & $0.249^{*}$ & $0.040^{* * *}$ & 0.075 & $-0.052^{* * *}$ & -0.044 \\
\hline & [0.04] & [0.15] & {$[0.01]$} & [0.05] & [0.02] & {$[0.05]$} \\
\hline \multirow[t]{2}{*}{ constant } & $1.730^{* * *}$ & 0.387 & $0.152^{* * *}$ & 0.646 & $1.353^{* * *}$ & $3.696^{* * *}$ \\
\hline & [0.23] & [3.19] & [0.05] & {$[0.83]$} & [0.11] & [1.20] \\
\hline Obs. & 4750 & 4750 & 4750 & 4750 & 4750 & 4750 \\
\hline Banks & 2442 & 2442 & 2442 & 2442 & 2442 & 2442 \\
\hline Instr. & & 16 & & 17 & & 17 \\
\hline $\mathrm{R}^{2}$ & 0.15 & & 0.03 & & 0.02 & \\
\hline $\mathrm{AR}(1)$ & & -5.08 & & -3.55 & & -6.79 \\
\hline $\mathrm{AR}(2)$ & & -1.27 & & -1.09 & & -1.46 \\
\hline Hansen & & 0.83 & & 0.84 & & 0.84 \\
\hline
\end{tabular}

Notes: We assess the effects of bank profitability related to negative interest rates on risk-taking. Notes: The sample comprises annual data of 2442 European banks operating in 28 countries from European Union over the period 2011-2017. The estimations are based on OLS estimator and the Arellano and Bond (1991) System GMM estimator (or two-step dynamic panel estimation). The $\mathrm{t}$-statistics based on Windmeijer (2005) correction of variance is reported in parentheses. ${ }^{* *},{ }^{* *}$ and ${ }^{*}$ are statistical significances at 0.01 , 0.05 and 0.10 level, respectively. AR (1) and AR (2) are the test for first and second-order autocorrelation and Hansen is the p-value of the Hansen test for over-identifying restrictions. The command "collapse" is used to limit the number of instruments. Table A gives the definitions of the variables. 
Table G - The effects of negative rates on small banks

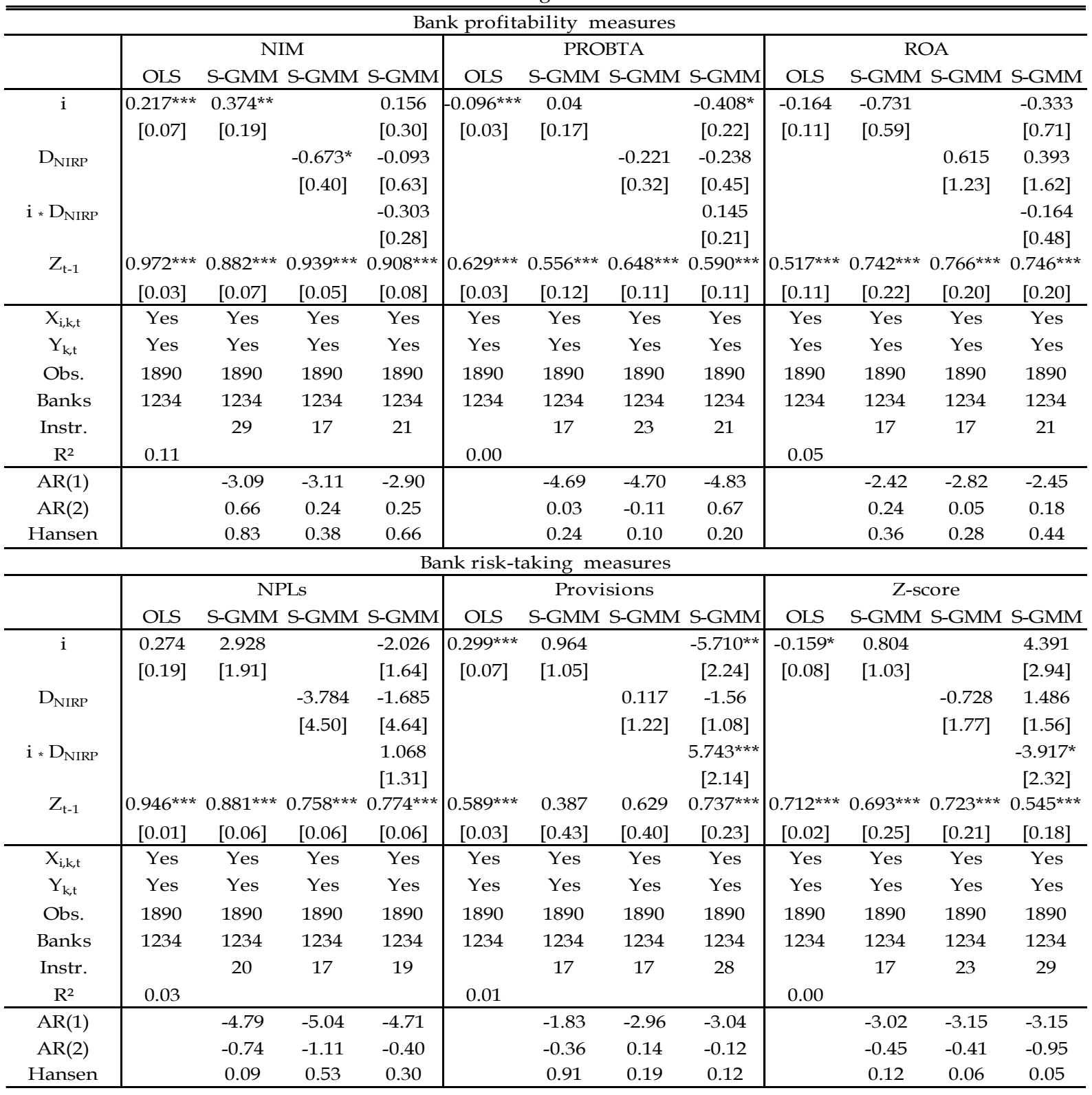

Notes: The sample comprises annual data of 2442 European banks operating in 28 countries from European Union over the period 2011-2017. The estimations are based on OLS estimator and the Arellano and Bond (1991) System GMM estimator (or two-step dynamic panel estimation). $X_{i, k, t}$ and $Y_{k, t}$ are banks'specific and country'specific controls.The t-statistics based on Windmeijer (2005) correction of variance is reported in parentheses. ${ }^{* * *}$, ${ }^{* *}$ and * are statistical significances at $0.01,0.05$ and 0.10 level, respectively. AR (1) and AR (2) are the test for first and second-order autocorrelation and Hansen is the p-value of the Hansen test for overidentifying restrictions. The command "collapse" is used to limit the number of instruments. Table A gives the definitions of the variables. 
Table $\mathbf{H}$ - The effects of negative rates on large banks

\begin{tabular}{|c|c|c|c|c|c|c|c|c|c|c|c|c|}
\hline \multicolumn{13}{|c|}{ Bank profitability measures } \\
\hline & \multicolumn{4}{|c|}{ NIM } & \multicolumn{4}{|c|}{ PROBTA } & \multicolumn{4}{|c|}{ ROA } \\
\hline & OLS & S-GMM & S-GMM & S-GMM & OLS & S-GMM & S-GMM & S-GMM & OLS & S-GMM & S-GMM & S-GMM \\
\hline \multirow[t]{2}{*}{$\mathrm{i}$} & $0.103^{* *}$ & $0.917^{* * *}$ & & -0.08 & -0.003 & -0.278 & & $0.831^{* *}$ & -0.086 & $-1.435^{* *}$ & & 0.902 \\
\hline & {$[0.05]$} & {$[0.24]$} & & {$[0.75]$} & {$[0.02]$} & {$[0.19]$} & & {$[0.33]$} & {$[0.08]$} & {$[0.70]$} & & {$[0.96]$} \\
\hline \multirow[t]{2}{*}{$\mathrm{D}_{\mathrm{NIRP}}$} & & & $-0.880^{* *}$ & -0.212 & & & 0.003 & $0.448^{* *}$ & & & -0.101 & -0.023 \\
\hline & & & {$[0.37]$} & {$[0.38]$} & & & {$[0.10]$} & {$[0.17]$} & & & {$[0.25]$} & {$[0.36]$} \\
\hline \multirow[t]{2}{*}{$\mathrm{i} * \mathrm{D}_{\mathrm{NIRP}}$} & & & & 0.72 & & & & -0.547 & & & & -0.996 \\
\hline & & & & [0.68] & & & & [0.34] & & & & [0.97] \\
\hline \multirow[t]{2}{*}{$Z_{t-1}$} & $0.946^{* * *}$ & $0.497^{* * *}$ & $0.479 * * *$ & $0.518^{* * *}$ & $0.624^{* * *}$ & $0.651^{* *}$ & $0.671^{* * *}$ & $0.877^{* * *}$ & $0.346^{* * *}$ & $0.379^{* *}$ & $0.392^{* * *}$ & $0.769^{* * *}$ \\
\hline & {$[0.01]$} & [0.10] & [0.14] & {$[0.11]$} & [0.02] & [0.32] & [0.15] & {$[0.23]$} & [0.05] & [0.16] & [0.09] & {$[0.26]$} \\
\hline$X_{i, k, t}$ & Yes & Yes & Yes & Yes & Yes & Yes & Yes & Yes & Yes & Yes & Yes & Yes \\
\hline $\mathrm{Y}_{\mathrm{k}, \mathrm{t}}$ & Yes & Yes & Yes & Yes & Yes & Yes & Yes & Yes & Yes & Yes & Yes & Yes \\
\hline Obs. & 2753 & 2753 & 2753 & 2753 & 2753 & 2753 & 2753 & 2753 & 2753 & 2753 & 2753 & 2753 \\
\hline Banks & 1196 & 1196 & 1196 & 1196 & 1196 & 1196 & 1196 & 1196 & 1196 & 1196 & 1196 & 1196 \\
\hline Instr. & & 23 & 17 & 21 & & 15 & 15 & 21 & & 17 & 30 & 30 \\
\hline $\mathrm{R}^{2}$ & 0.20 & & & & 0.03 & & & & 0.03 & & & \\
\hline $\mathrm{AR}(1)$ & & -2.60 & -2.35 & -2.68 & & -4.04 & -4.98 & -4.78 & & -2.51 & -2.32 & -2.52 \\
\hline $\mathrm{AR}(2)$ & & 0.03 & -0.22 & -0.04 & & 1.70 & 1.62 & 1.57 & & -0.97 & -0.37 & 0.54 \\
\hline \multirow[t]{4}{*}{ Hansen } & & 0.95 & 0.62 & 0.74 & & 0.35 & 0.42 & 0.17 & & 0.90 & 0.14 & 0.09 \\
\hline & \multicolumn{8}{|c|}{ Bank risk-taking measures } & & & & \\
\hline & \multicolumn{4}{|c|}{ NPLs } & \multicolumn{4}{|c|}{ Provisions } & \multicolumn{4}{|c|}{ Z-score } \\
\hline & OLS & S-GMM & S-GMM & S-GMM & OLS & S-GMM & S-GMM & S-GMM & OLS & S-GMM & S-GMM & S-GMM \\
\hline \multirow[t]{2}{*}{$\bar{i}$} & 0.23 & 1.005 & & -1.775 & $0.168^{* * *}$ & $0.566^{* * *}$ & & -0.283 & $-0.200^{* * *}$ & -0.503 & & 0.175 \\
\hline & [0.15] & [1.94] & & [3.58] & [0.03] & [0.21] & & [1.40] & {$[0.06]$} & {$[0.40]$} & & [0.19] \\
\hline \multirow[t]{2}{*}{$\mathrm{D}_{\mathrm{NIRP}}$} & & & -0.167 & $-6.054^{*}$ & & & $-0.248^{*}$ & 0.043 & & & $0.648^{* * *}$ & $0.918^{* * *}$ \\
\hline & & & {$[0.45]$} & [3.28] & & & [0.15] & {$[0.36]$} & & & [0.25] & [0.28] \\
\hline \multirow[t]{2}{*}{$\mathrm{i} * \mathrm{D}_{\mathrm{NIRP}}$} & & & & -6.865 & & & & 0.33 & & & & 0.233 \\
\hline & & & & [6.45] & & & & [1.44] & & & & {$[0.24]$} \\
\hline \multirow[t]{2}{*}{$\mathrm{Z}_{\mathrm{t}-1}$} & $0.911^{* * *}$ & $0.653^{* * *}$ & $0.918^{* * *}$ & $0.868^{* * *}$ & $0.677^{* * *}$ & 0.66 & $0.939^{* * *}$ & $0.386^{* *}$ & $0.761^{* * *}$ & $0.617^{* * *}$ & $0.787^{* * *}$ & $0.636^{* * *}$ \\
\hline & [0.01] & [0.20] & [0.06] & [0.15] & {$[0.02]$} & {$[0.41]$} & [0.20] & [0.19] & [0.01] & [0.09] & [0.04] & [0.15] \\
\hline $\mathrm{X}_{\mathrm{i}, \mathrm{k}, \mathrm{t}}$ & Yes & Yes & Yes & Yes & Yes & Yes & Yes & Yes & Yes & Yes & Yes & Yes \\
\hline $\mathrm{Y}_{\mathrm{k}, \mathrm{t}}$ & Yes & Yes & Yes & Yes & Yes & Yes & Yes & Yes & Yes & Yes & Yes & Yes \\
\hline Obs. & 2753 & 2753 & 2753 & 2753 & 2753 & 2753 & 2753 & 2753 & 2753 & 2753 & 2753 & 2753 \\
\hline Banks & 1196 & 1196 & 1196 & 1196 & 1196 & 1196 & 1196 & 1196 & 1196 & 1196 & 1196 & 1196 \\
\hline Instr. & & 15 & 26 & 22 & & 20 & 24 & 20 & & 23 & 30 & 34 \\
\hline $\mathrm{R}^{2}$ & 0.21 & & & & 0.05 & & & & 0.04 & & & \\
\hline $\operatorname{AR}(1)$ & & -3.54 & -3.40 & -3.38 & & -1.96 & -3.17 & -2.29 & & -5.55 & -9.09 & -3.78 \\
\hline $\mathrm{AR}(2)$ & & -0.65 & -1.24 & -0.14 & & -0.43 & -0.22 & -0.62 & & -1.37 & -0.87 & -0.98 \\
\hline Hansen & & 0.86 & 0.24 & 0.64 & & 0.43 & 0.19 & 0.17 & & 0.09 & 0.21 & 0.19 \\
\hline
\end{tabular}

Notes: The sample comprises annual data of 2442 European banks operating in 28 countries from European Union over the period 2011-2017. The estimations are based on OLS estimator and the Arellano and Bond (1991) System GMM estimator (or two-step dynamic panel estimation). $X_{i, k, t}$ and $Y_{k, t}$ are banks'specific and country'specific controls. The t-statistics based on Windmeijer (2005) correction of variance is reported in parentheses. ${ }^{* * *},{ }^{* *}$ and * are statistical significances at $0.01,0.05$ and 0.10 level, respectively. AR (1) and AR (2) are the test for first and second-order autocorrelation and Hansen is the p-value of the Hansen test for overidentifying restrictions. The command "collapse" is used to limit the number of instruments. Table A gives the definitions of the variables. 
Table I - The effects of negative rates on banks with low liquidity

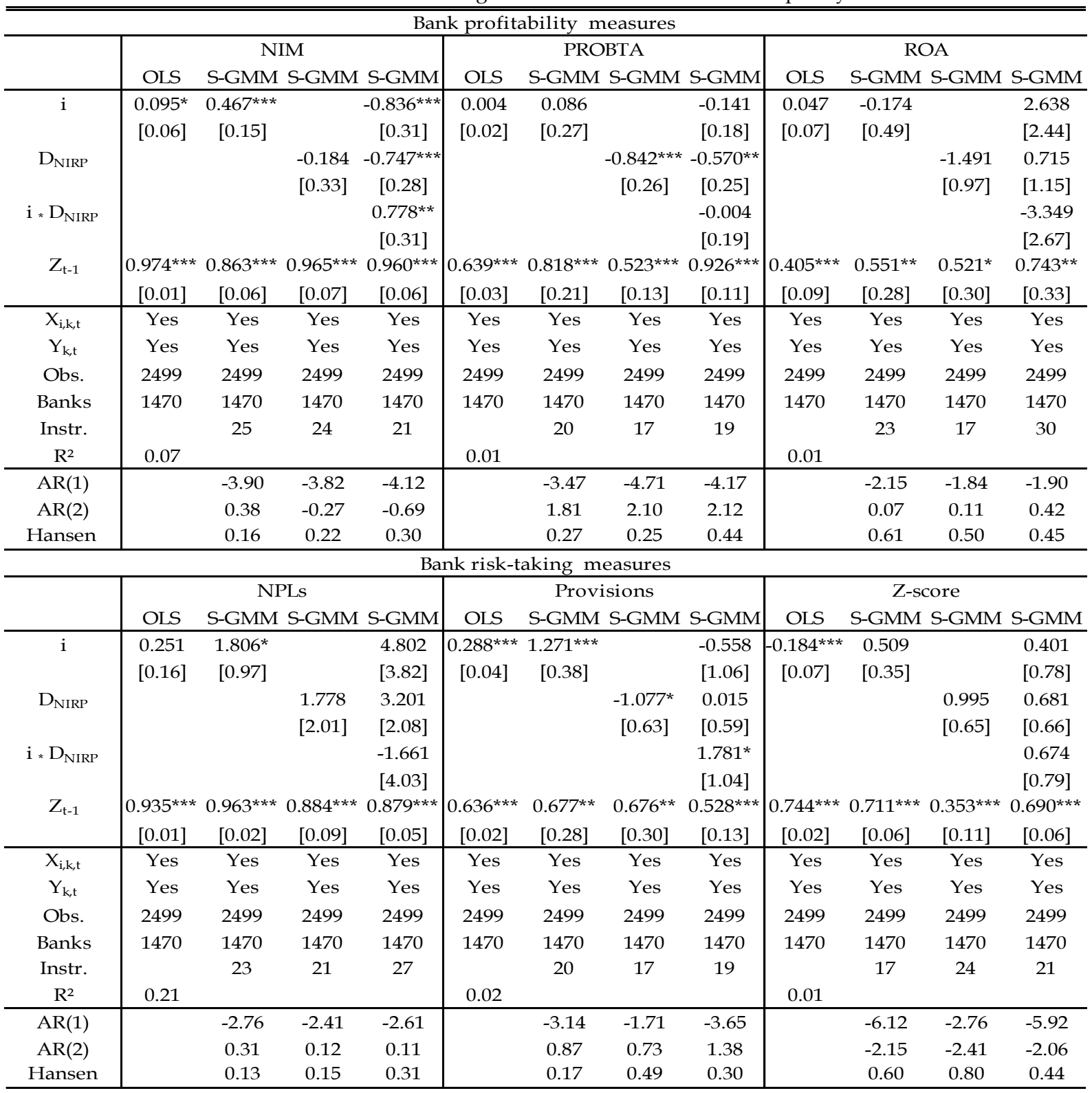

Notes: Notes: The sample comprises annual data of 2442 European banks operating in 28 countries from European Union over the period 2011-2017. The estimations are based on OLS estimator and the Arellano and Bond (1991) System GMM estimator (or two-step dynamic panel estimation). $X_{\mathrm{i}, \mathrm{k}, \mathrm{t}}$ and $\mathrm{Y}_{\mathrm{k}, \mathrm{t}}$ are banks'specific and country'specific controls.The t-statistics based on Windmeijer (2005) correction of variance is reported in parentheses. ***, ** and * are statistical significances at $0.01,0.05$ and 0.10 level, respectively. AR (1) and AR (2) are the test for first and second-order autocorrelation and Hansen is the p-value of the Hansen test for overidentifying restrictions. The command "collapse" is used to limit the number of instruments. Table A gives the definitions of the variables. 
Table J - The effects of negative rates on banks with high liquidity

\begin{tabular}{|c|c|c|c|c|c|c|c|c|c|c|c|c|}
\hline \multicolumn{13}{|c|}{ Bank profitability measures } \\
\hline & \multicolumn{4}{|c|}{ NIM } & \multicolumn{4}{|c|}{ PROBTA } & \multicolumn{4}{|c|}{ ROA } \\
\hline & OLS & S-GMM & S-GMM & S-GMM & OLS & S-GMM & S-GMM & S-GMM & OLS & S-GMM & S-GMM & S-GMM \\
\hline \multirow[t]{2}{*}{ i } & $0.140^{* * *}$ & $0.371^{* * *}$ & & 0.183 & $-0.058^{*}$ & -0.06 & & $0.602^{*}$ & $-0.252^{* * *}$ & 0.224 & & 0.726 \\
\hline & [0.05] & [0.10] & & [0.18] & [0.03] & [0.35] & & [0.32] & [0.09] & [0.65] & & [1.01] \\
\hline \multirow{2}{*}{$\mathrm{D}_{\mathrm{NIRP}}$} & & & -0.233 & 0.087 & & & $0.267^{*}$ & 0.21 & & & 0.436 & 0.449 \\
\hline & & & {$[0.18]$} & {$[0.20]$} & & & {$[0.14]$} & {$[0.20]$} & & & {$[0.32]$} & {$[0.36]$} \\
\hline \multirow[t]{2}{*}{$\mathrm{i} * \mathrm{D}_{\mathrm{NIRP}}$} & & & & 0.076 & & & & $-0.614^{* *}$ & & & & -0.282 \\
\hline & & & & [0.19] & & & & {$[0.30]$} & & & & [0.96] \\
\hline \multirow[t]{2}{*}{$\mathrm{Z}_{\mathrm{t}-1}$} & $0.896^{* * *}$ & $0.684^{* * *}$ & $0.868^{* * *}$ & $0.887^{* * *}$ & $0.576^{* * *}$ & $0.793^{* * *}$ & $0.373^{* * *}$ & $0.533^{* * *}$ & $0.362^{* * *}$ & $0.425^{\star *}$ & $0.335^{* *}$ & $0.431^{* * *}$ \\
\hline & {$[0.03]$} & {$[0.11]$} & [0.11] & [0.09] & [0.03] & [0.25] & {$[0.08]$} & {$[0.18]$} & [0.09] & [0.18] & [0.13] & {$[0.14]$} \\
\hline$X_{i, k, t}$ & Yes & Yes & Yes & Yes & Yes & Yes & Yes & Yes & Yes & Yes & Yes & Yes \\
\hline $\mathrm{Y}_{\mathrm{k}, \mathrm{t}}$ & Yes & Yes & Yes & Yes & Yes & Yes & Yes & Yes & Yes & Yes & Yes & Yes \\
\hline Obs. & 1742 & 1742 & 1742 & 1742 & 1742 & 1742 & 1742 & 1742 & 1742 & 1742 & 1742 & 1742 \\
\hline Banks & 897 & 897 & 897 & 897 & 897 & 897 & 897 & 897 & 897 & 897 & 897 & 897 \\
\hline \multirow{2}{*}{$\begin{array}{c}\text { Instr. } \\
\mathrm{R}^{2}\end{array}$} & & 25 & 29 & 29 & & 17 & 30 & 29 & & 23 & 23 & 29 \\
\hline & 0.18 & & & & 0.02 & & & & 0.02 & & & \\
\hline $\mathrm{AR}(1)$ & & -2.03 & -1.98 & -2.03 & & -3.47 & -4.62 & -3.87 & & -1.80 & -1.97 & -2.02 \\
\hline \multirow{2}{*}{$\begin{array}{c}\text { AR(2) } \\
\text { Hansen }\end{array}$} & & 0.53 & 0.42 & 0.69 & & 1.13 & 0.78 & 1.41 & & 1.46 & 1.40 & 1.65 \\
\hline & & 0.15 & 0.39 & 0.10 & & 0.10 & 0.15 & 0.20 & & 0.59 & 0.95 & 0.14 \\
\hline \multicolumn{13}{|c|}{ Bank risk-taking measures } \\
\hline & \multicolumn{4}{|c|}{ NPLs } & \multicolumn{4}{|c|}{ Provisions } & \multicolumn{4}{|c|}{ Z-score } \\
\hline & OLS & S-GMM & S-GMM & S-GMM & OLS & S-GMM & S-GMM & S-GMM & OLS & S-GMM & S-GMM & S-GMM \\
\hline \multirow[t]{2}{*}{$\mathrm{i}$} & $0.413^{*}$ & $1.093^{*}$ & & $-1.878^{*}$ & $0.220^{* * *}$ & 0.13 & & -0.066 & $-0.197^{* * *}$ & 0.07 & & 0.677 \\
\hline & [0.23] & [0.63] & & [1.14] & [0.05] & [0.16] & & {$[0.24]$} & {$[0.06]$} & [0.19] & & [0.63] \\
\hline \multirow[t]{2}{*}{$\mathrm{D}_{\text {NIRP }}$} & & & $-2.206^{* *}$ & -2.303 & & & 0.104 & -0.315 & & & $0.741^{* *}$ & $0.907^{* *}$ \\
\hline & & & [0.99] & [1.64] & & & [0.50] & [0.32] & & & [0.33] & {$[0.46]$} \\
\hline \multirow[t]{2}{*}{$\mathrm{i} * \mathrm{D}_{\mathrm{NIRP}}$} & & & & $2.059 *$ & & & & 0.122 & & & & -0.216 \\
\hline & & & & [1.10] & & & & {$[0.21]$} & & & & [0.56] \\
\hline \multirow[t]{2}{*}{$Z_{t-1}$} & $0.862^{* * *}$ & $0.844^{* * *}$ & $0.793^{* * *}$ & $0.853^{* * *}$ & $0.573^{* * *}$ & $0.601^{* * *}$ & $0.916^{* *}$ & $0.507^{* * *}$ & $0.724^{* * *}$ & $0.833^{* * *}$ & $0.587^{* * *}$ & $0.566^{* * *}$ \\
\hline & [0.02] & [0.10] & [0.06] & [0.12] & [0.03] & [0.21] & [0.42] & [0.10] & [0.02] & [0.05] & {$[0.10]$} & [0.10] \\
\hline$X_{i, k, t}$ & Yes & Yes & Yes & Yes & Yes & Yes & Yes & Yes & Yes & Yes & Yes & Yes \\
\hline$Y_{k, t}$ & Yes & Yes & Yes & Yes & Yes & Yes & Yes & Yes & Yes & Yes & Yes & Yes \\
\hline Obs. & 1742 & 1742 & 1742 & 1742 & 1742 & 1742 & 1742 & 1742 & 1742 & 1742 & 1742 & 1742 \\
\hline Banks & 897 & 897 & 897 & 897 & 897 & 897 & 897 & 897 & 897 & 897 & 897 & 897 \\
\hline Instr. & & 25 & 24 & 19 & & 25 & 17 & 21 & & 29 & 17 & 29 \\
\hline $\mathrm{R}^{2}$ & 0.10 & & & & 0.05 & & & & 0.02 & & & \\
\hline $\operatorname{AR}(1)$ & & -3.40 & -3.88 & -3.20 & & -2.44 & -2.15 & -4.66 & & -7.23 & -4.33 & -4.08 \\
\hline $\mathrm{AR}(2)$ & & -3.37 & -3.27 & -3.46 & & -0.59 & -0.31 & -0.88 & & -1.42 & -1.47 & -1.35 \\
\hline Hansen & & 0.35 & 0.10 & 0.65 & & 0.17 & 0.26 & 0.11 & & 0.11 & 0.16 & 0.11 \\
\hline
\end{tabular}

Notes: The sample comprises annual data of 2442 European banks operating in 28 countries from European Union over the period 2011-2017. The estimations are based on OLS estimator and the Arellano and Bond (1991) System GMM estimator (or two-step dynamic panel estimation). $X_{i, k, t}$ and $Y_{k, t}$ are banks'specific and country'specific controls. The t-statistics based on Windmeijer (2005) correction of variance is reported in parentheses. ${ }^{* * *},{ }^{* *}$ and * are statistical significances at $0.01,0.05$ and 0.10 level, respectively. AR (1) and AR (2) are the test for first and second-order autocorrelation and Hansen is the p-value of the Hansen test for overidentifying restrictions. The command "collapse" is used to limit the number of instruments. Table A gives the definitions of the variables. 
Table K - The effects of negative interest rate policy on European banks (last observation of $i$ )

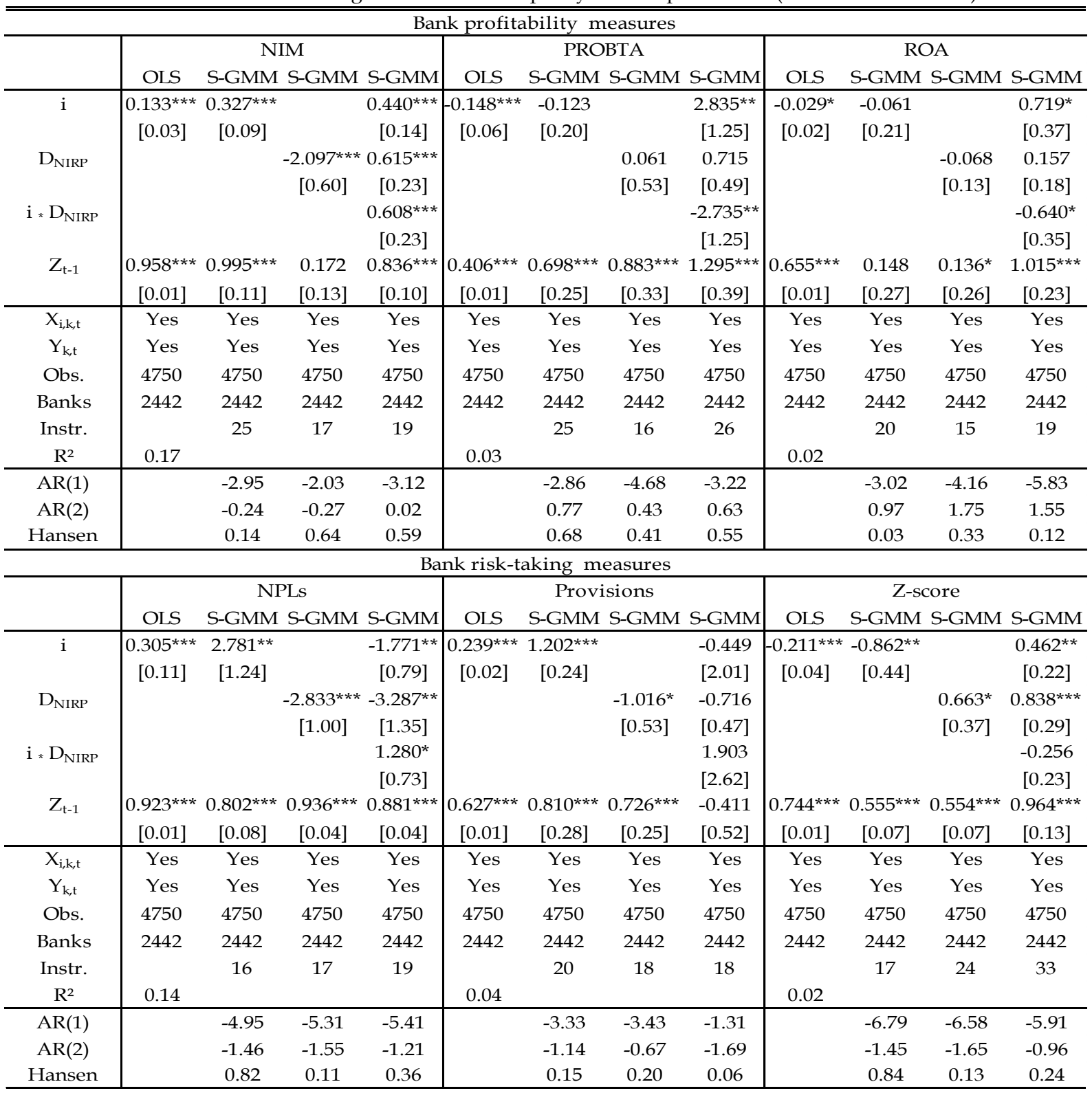

Notes: The sample comprises annual data of 2442 European banks operating in 28 countries from European Union over the period 2011-2017. The estimations are based on OLS estimator and the Arellano and Bond (1991) System GMM estimator (or two-step dynamic panel estimation). $X_{i, k, t}$ and $Y_{k, t}$ are banks'specific and country'specific controls. The t-statistics based on Windmeijer (2005) correction of variance is reported in parentheses. ${ }^{* * *}$,** and * are statistical significances at $0.01,0.05$ and 0.10 level, respectively. AR (1) and AR (2) are the test for first and second-order autocorrelation and Hansen is the p-value of the Hansen test for overidentifying restrictions. The command "collapse" is used to limit the number of instruments. Table A gives the definitions of the variables. 
Table L - The effects of the negative interest rate policy on European Union banks (without Germany)

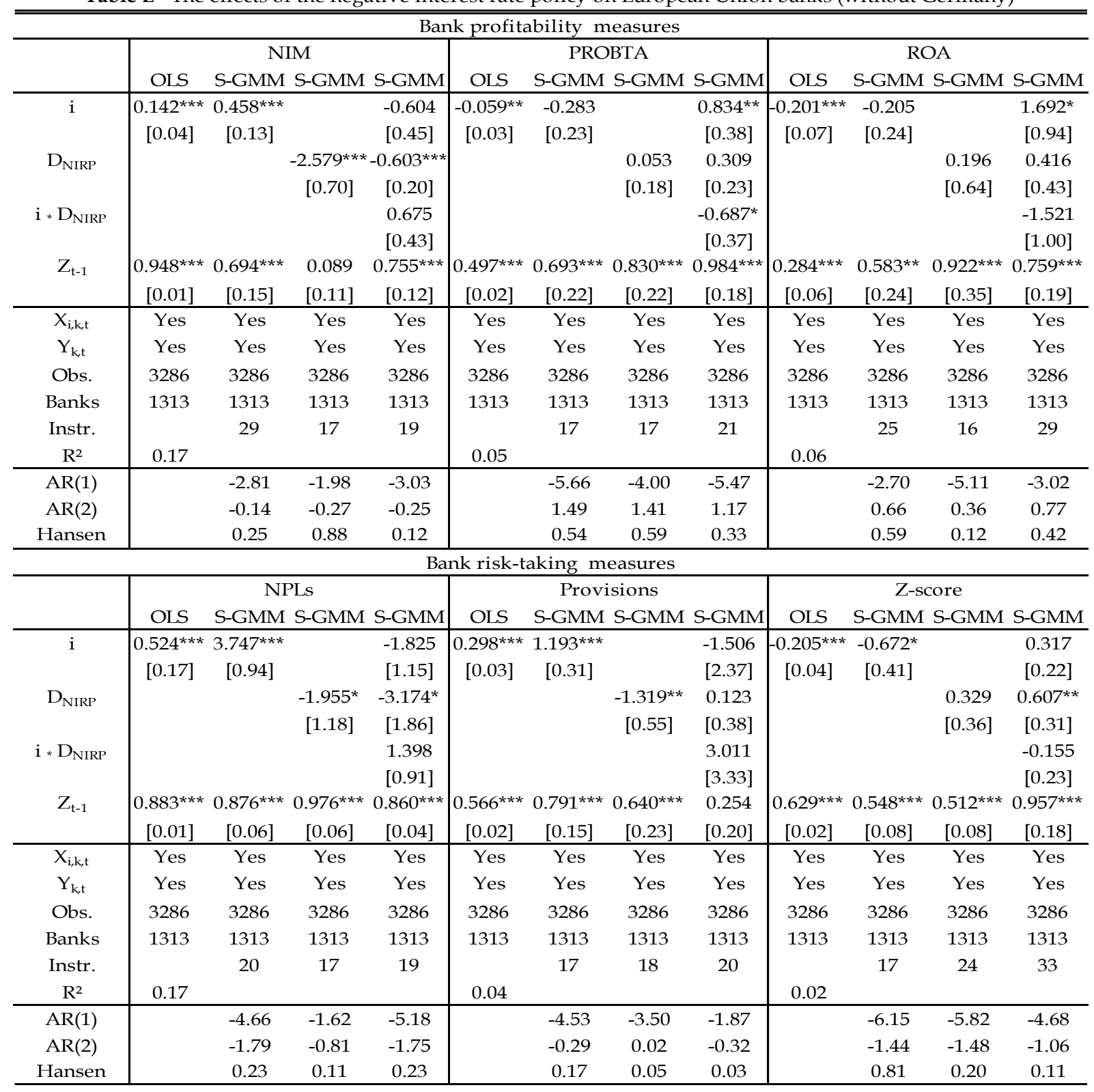

Notes: The sample comprises annual data of 2442 European banks operating in 28 countries from European Union over the period 2011-2017. The estimations are based on OLS estimator and the Arellano and Bond (1991) System GMM estimator (or two-step dynamic panel estimation). $X_{i, k, t}$ and $Y_{k, t}$ are banks'specific and country'specific controls. The t-statistics based on Windmeijer (2005) correction of variance is reported in parentheses. ${ }^{* * *},{ }^{* *}$ and * are statistical significances at $0.01,0.05$ and 0.10 level, respectively. AR (1) and AR (2) are the test for first and second-order autocorrelation and Hansen is the p-value of the Hansen test for overidentifying restrictions. The command "collapse" is used to limit the number of instruments. Table A gives the definitions of the variables. 
Table M - The effects of the negative interest rate policy on European Union banks (without the UK)

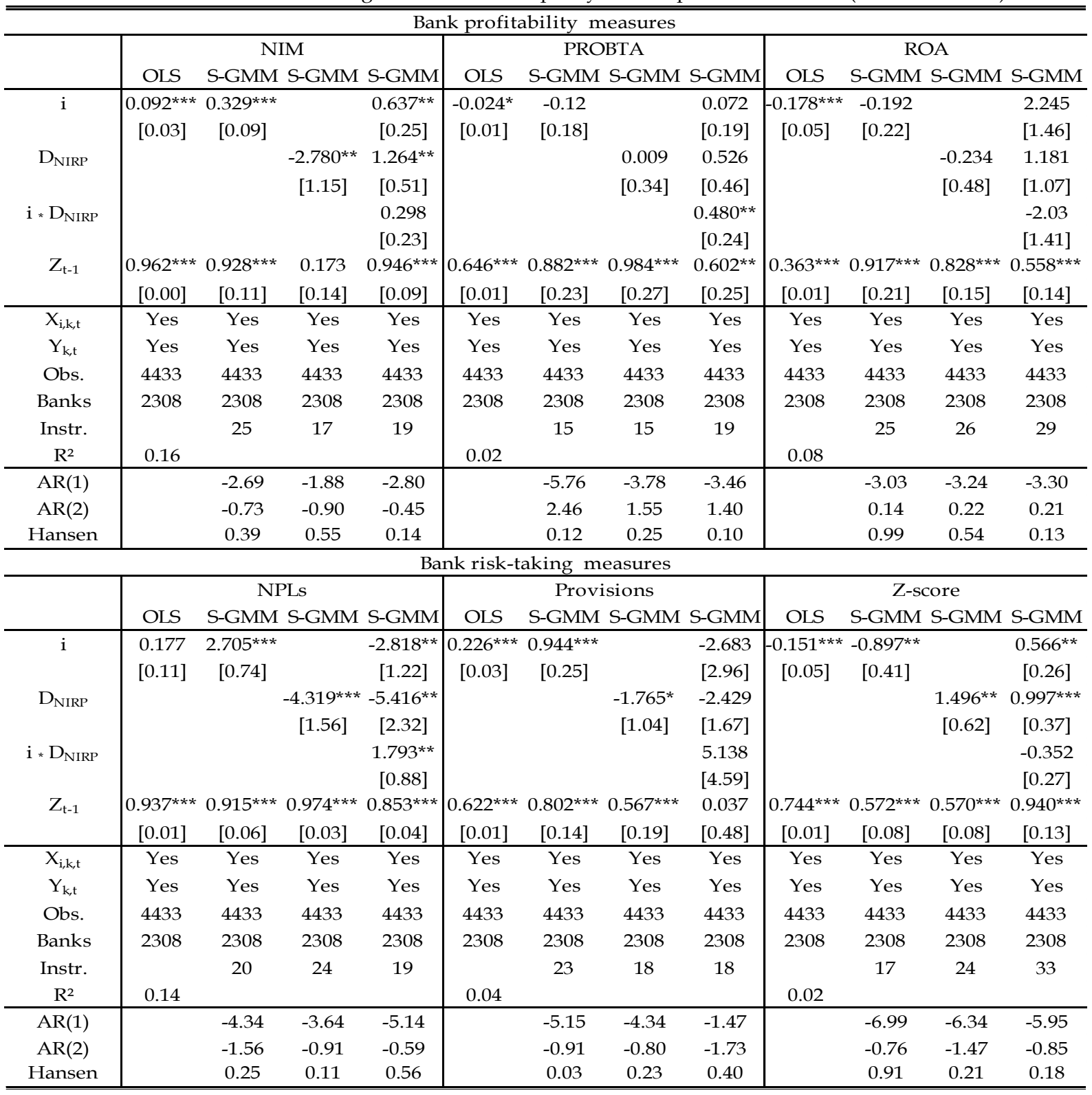

Notes: The sample comprises annual data of 2442 European banks operating in 28 countries from European Union over the period 2011-2017. The estimations are based on OLS estimator and the Arellano and Bond (1991) System GMM estimator (or two-step dynamic panel estimation). $X_{i, k, t}$ and $Y_{k, t}$ are banks'specific and country'specific controls. The t-statistics based on Windmeijer (2005) correction of variance is reported in parentheses. ${ }^{* * *},{ }^{* *}$ and * are statistical significances at $0.01,0.05$ and 0.10 level, respectively. AR (1) and AR (2) are the test for first and second-order autocorrelation and Hansen is the p-value of the Hansen test for overidentifying restrictions. The command "collapse" is used to limit the number of instruments. Table A gives the definitions of the variables. 
Table N - The effects of negative interest rate policy on European banks (countries with NIRP)

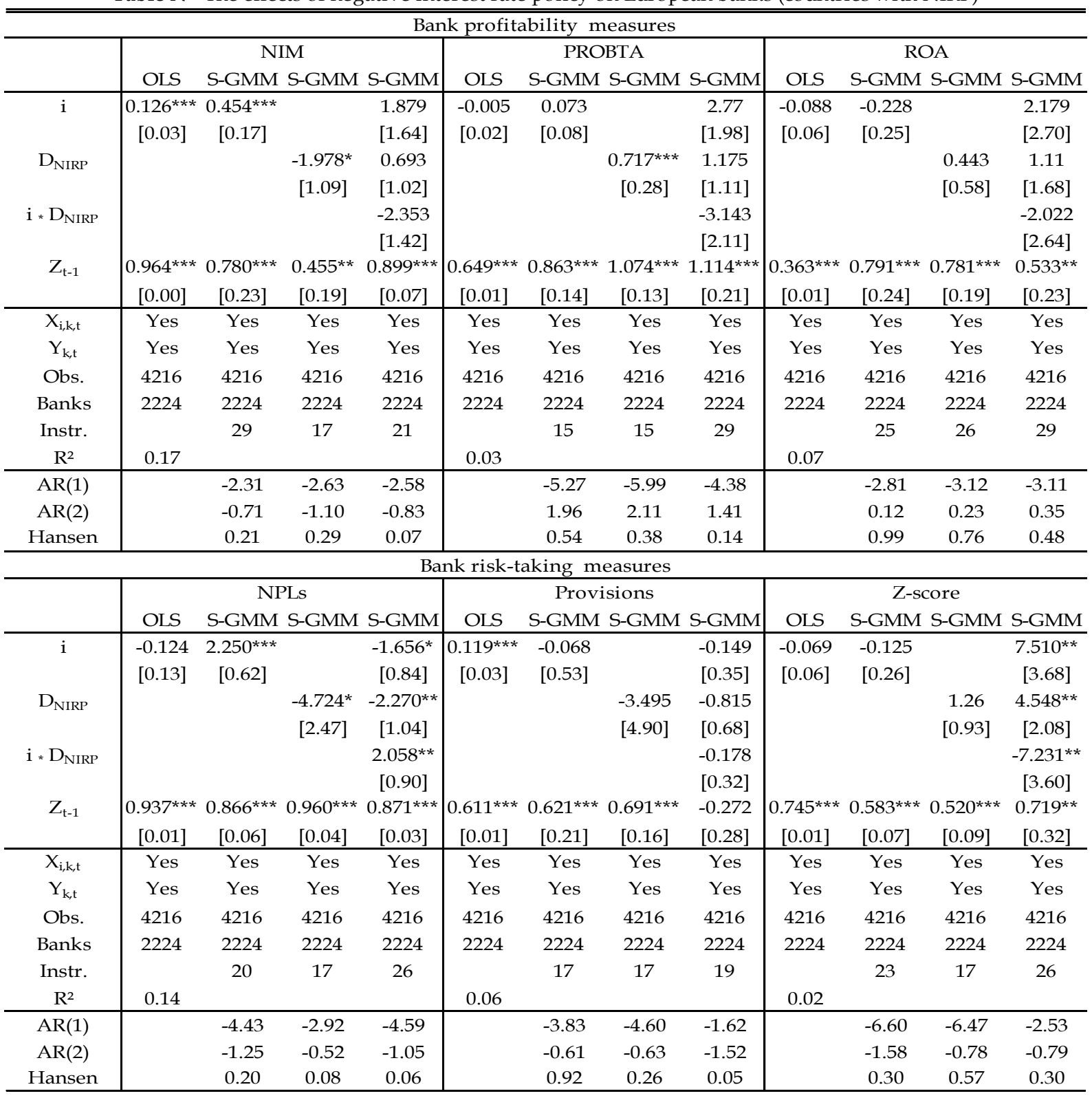

Notes: The sample comprises annual data of 2442 European banks operating in 28 countries from European Union over the period 2011-2017. The estimations are based on OLS estimator and the Arellano and Bond (1991) System GMM estimator (or two-step dynamic panel estimation). $X_{i, k, t}$ and $Y_{k, t}$ are banks'specific and country'specific controls.The t-statistics based on Windmeijer (2005) correction of variance is reported in parentheses. ${ }^{* * *},{ }^{* *}$ and * are statistical significances at $0.01,0.05$ and 0.10 level, respectively. AR (1) and AR (2) are the test for first and second-order autocorrelation and Hansen is the p-value of the Hansen test for overidentifying restrictions. The command "collapse" is used to limit the number of instruments. Table A gives the definitions of the variables. 
Table O - The effects of interbank rate on European banks

\begin{tabular}{|c|c|c|c|c|c|c|c|c|c|c|c|c|}
\hline \multicolumn{13}{|c|}{ Bank profitability measures } \\
\hline & \multicolumn{4}{|c|}{ NIM } & \multicolumn{4}{|c|}{ PROBTA } & \multicolumn{4}{|c|}{ ROA } \\
\hline & OLS & S-GMM & S-GMM & S-GMM & OLS & S-GMM & S-GMM & S-GMM & OLS & S-GMM & S-GMM & S-GMM \\
\hline \multirow[t]{2}{*}{ inter } & $0.049^{* *}$ & $0.376^{* * *}$ & & 0.154 & -0.001 & -0.063 & & 0.122 & $-0.123^{* * *}$ & -0.119 & & 0.22 \\
\hline & {$[0.02]$} & {$[0.08]$} & & {$[0.11]$} & {$[0.01]$} & {$[0.08]$} & & {$[0.25]$} & {$[0.04]$} & {$[0.13]$} & & {$[0.14]$} \\
\hline \multirow[t]{2}{*}{$\mathrm{D}_{\text {inter }}$} & & & -0.04 & -0.016 & & & -0.108 & 0.096 & & & -0.08 & -0.037 \\
\hline & & & {$[0.11]$} & {$[0.04]$} & & & {$[0.11]$} & [0.22] & & & [0.05] & [0.07] \\
\hline \multirow[t]{2}{*}{ inter $* D_{\text {inter }}$} & & & & $0.282^{* *}$ & & & & 0.597 & & & & $-0.445^{* *}$ \\
\hline & & & & {$[0.13]$} & & & & [0.97] & & & & {$[0.22]$} \\
\hline \multirow[t]{2}{*}{$\mathrm{Z}_{\mathrm{t}-1}$} & $0.959 * * *$ & $0.758^{* * *}$ & $0.871^{\text {*** }}$ & $0.666^{* * *}$ & $0.656^{* * *}$ & $1.268^{* * *}$ & $0.882^{*}$ & $0.866^{* *}$ & $0.410^{* * *}$ & $0.737^{* * *}$ & $0.798^{* * *}$ & $0.723^{* * *}$ \\
\hline & {$[0.00]$} & {$[0.15]$} & {$[0.08]$} & [0.14] & {$[0.01]$} & {$[0.24]$} & {$[0.47]$} & {$[0.46]$} & {$[0.01]$} & {$[0.21]$} & {$[0.30]$} & [0.19] \\
\hline$X_{i, k, t}$ & Yes & Yes & Yes & Yes & Yes & Yes & Yes & Yes & Yes & Yes & Yes & Yes \\
\hline$Y_{k, t}$ & Yes & Yes & Yes & Yes & Yes & Yes & Yes & Yes & Yes & Yes & Yes & Yes \\
\hline Obs. & 4750 & 4750 & 4750 & 4750 & 4750 & 4750 & 4750 & 4750 & 4750 & 4750 & 4750 & 4750 \\
\hline Banks & 2442 & 2442 & 2442 & 2442 & 2442 & 2442 & 2442 & 2442 & 2442 & 2442 & 2442 & 2442 \\
\hline Instr. & & 15 & 18 & 19 & & 15 & 16 & 19 & & 26 & 15 & 32 \\
\hline $\mathrm{R}^{2}$ & 0.17 & & & & 0.02 & & & & 0.02 & & & \\
\hline $\mathrm{AR}(1)$ & & -2.50 & -3.10 & -2.69 & & -4.68 & -2.47 & -2.68 & & -3.11 & -2.41 & -3.16 \\
\hline $\mathrm{AR}(2)$ & & -0.05 & -0.15 & -0.05 & & 1.83 & 1.35 & 1.55 & & 0.91 & 0.43 & 1.12 \\
\hline Hansen & & 0.58 & 0.69 & 0.51 & & 0.85 & 0.23 & 0.09 & & 0.30 & 0.58 & 0.10 \\
\hline \multicolumn{13}{|c|}{ Bank risk-taking measures } \\
\hline & \multicolumn{4}{|c|}{ NPLs } & \multicolumn{4}{|c|}{ Provisions } & \multicolumn{4}{|c|}{ Z-score } \\
\hline & OLS & S-GMM & S-GMM & S-GMM & OLS & S-GMM & S-GMM & S-GMM & OLS & S-GMM & S-GMM & S-GMM \\
\hline \multirow[t]{2}{*}{ inter } & $0.373^{* * *}$ & -0.84 & & 0.364 & $0.225^{* * *}$ & $-0.094^{* *}$ & & 0.029 & $-0.200^{* * *}$ & $-0.694^{*}$ & & $-0.266^{* *}$ \\
\hline & {$[0.09]$} & {$[0.60]$} & & [0.27] & {$[0.02]$} & {$[0.05]$} & & {$[0.16]$} & {$[0.04]$} & {$[0.36]$} & & {$[0.11]$} \\
\hline \multirow[t]{2}{*}{$\mathrm{D}_{\text {inter }}$} & & & -0.57 & $0.302^{*}$ & & & $-0.450^{* * *}$ & 0.203 & & & $0.356^{*}$ & -0.086 \\
\hline & & & [0.35] & {$[0.16]$} & & & {$[0.14]$} & {$[0.18]$} & & & {$[0.21]$} & {$[0.07]$} \\
\hline \multirow[t]{2}{*}{ inter $* \mathrm{D}_{\text {inter }}$} & & & & 0.732 & & & & 1.162 & & & & 0.156 \\
\hline & & & & {$[0.54]$} & & & & {$[0.86]$} & & & & {$[0.28]$} \\
\hline \multirow[t]{2}{*}{$\mathrm{Z}_{\mathrm{t}-1}$} & $0.922^{* * *}$ & $0.745^{* * *}$ & $0.991^{* * *}$ & $0.870^{* * *}$ & $0.626^{* * *}$ & $1.249^{* * *}$ & $1.448^{* * *}$ & $0.573^{* * *}$ & $0.741^{* * *}$ & $0.436^{* * *}$ & 0.189 & $0.971^{* * *}$ \\
\hline & [0.01] & {$[0.13]$} & {$[0.04]$} & [0.05] & {$[0.01]$} & [0.15] & {$[0.27]$} & {$[0.20]$} & {$[0.01]$} & {$[0.10]$} & {$[0.26]$} & [0.09] \\
\hline $\mathrm{X}_{\mathrm{i}, \mathrm{k}, \mathrm{t}}$ & Yes & Yes & Yes & Yes & Yes & Yes & Yes & Yes & Yes & Yes & Yes & Yes \\
\hline$Y_{k, t}$ & Yes & Yes & Yes & Yes & Yes & Yes & Yes & Yes & Yes & Yes & Yes & Yes \\
\hline Obs. & 4750 & 4750 & 4750 & 4750 & 4750 & 4750 & 4750 & 4750 & 4750 & 4750 & 4750 & 4750 \\
\hline Banks & 2442 & 2442 & 2442 & 2442 & 2442 & 2442 & 2442 & 2442 & 2442 & 2442 & 2442 & 2442 \\
\hline Instr. & & 16 & 23 & 19 & & 20 & 24 & 20 & & 17 & 17 & 19 \\
\hline $\mathrm{R}^{2}$ & 0.14 & & & & 0.04 & & & & 0.02 & & & \\
\hline $\operatorname{AR}(1)$ & & -4.36 & -4.31 & -5.12 & & -6.26 & -4.39 & -4.07 & & -2.50 & -0.91 & -7.12 \\
\hline $\mathrm{AR}(2)$ & & -0.90 & -1.44 & -1.21 & & 1.90 & 0.08 & -0.48 & & 0.23 & -2.09 & -1.33 \\
\hline Hansen & & 0.81 & 0.23 & 0.25 & & 0.49 & 0.17 & 0.90 & & 0.46 & 0.12 & 0.18 \\
\hline
\end{tabular}

Notes: The sample comprises annual data of 2442 European banks operating in 28 countries from European Union over the period 2011-2017. The estimations are based on OLS estimator and the Arellano and Bond (1991) System GMM estimator (or two-step dynamic panel estimation). $\mathrm{X}_{\mathrm{i}, \mathrm{k}, \mathrm{t}}$ and $\mathrm{Y}_{\mathrm{k}, \mathrm{t}}$ are banks'specific and country'specific controls. The t-statistics based on Windmeijer (2005) correction of variance is reported in parentheses. ${ }^{* *},{ }^{* *}$ and * are statistical significances at $0.01,0.05$ and 0.10 level, respectively. AR (1) and AR (2) are the test for first and second-order autocorrelation and Hansen is the p-value of the Hansen test for over-identifying restrictions. The command "collapse" is used to limit the number of instruments. Table A gives the definitions of the variables. 


\section{References}

Adrian T. and Shin S., (2010). Financial Intermediaries and Monetary Economics. Handbook of Monetary Economics, edition 1, volume 3, chapter 12, pages 601-650 Elsevier.

Adrian T. and Shin S., (2010). Liquidity and Leverage. Journal of Financial Intermediation, Vol. 19, No. 3 (July 2010), pp. 418-437.

Adrian T., Obstfeld M. and Tiwari S., (2017). Negative Interest Rate Policies -- Initial Experience and Assessments. IMF Policy Paper (March 13, 2017).

Aharony J., Saunders A. and Swary I., (1986). The effects of a shift in monetary policy regime on the profitability and risk of commercial banks. Journal of Monetary Economics, Vol. 17, No. 3 (May 1986), pp. 363-377.

Ahrend R., Boris Cournède B. and Price R., (2008). Monetary Policy, Market Excesses and Financial Turmoil. OECD Economics Department Working Papers 597, OECD Publishing.

Albertazzi U. and Gambacorta L., (2009). Bank Profitability and the Business Cycle. Journal of Financial Stability, Vol. 5, pp. 393-409.

Altavilla C., Boucinha M. and Peydró J-L., (2017). Monetary policy and bank profitability in a low interest rate environment. Working Paper Series 2105, European Central Bank.

Altman E., (1977). Predicting performance in the savings and loan association industry. Journal of Monetary Economic, Vol. 3, No. 4, pp. 443-466.

Andries A. M., Cocriș V. and Pleș cău I., (2016). Low Interest Rates and Bank Risk-taking: Has the Crisis Changed Anything? Evidence from the Eurozone. Review of Economic \& Business Studies, Vol. 8, issue 1, pp. 125-148.

Angrick S. and Nemoto N., (2017). Central Banking below Zero: The Implementation of Negative Interest Rate Policies in Europe and Japan. ADBI Working Papers 740, Asian Development Bank Institute.

Arcand J. L., Berkes E. and Panizza U., (2015). Too Much Finance?. Journal of Economic Growth, Vol. 20, pp. 105-148.

Arellano M. and Bond S., (1991). Some tests of specification for panel data: Monte Carlo evidence and an application to employment equations. The review of economic studies, Vol. 58, No. 2, pp. 277297.

Arellano M. and Bover O., (1995). Another look at the instrumental variable estimation of errorcomponents models. Journal of Econometrics, Vol. 68, No.1, pp. 29-51.

Arseneau D. M., (2017). How Would US Banks Fare in a Negative Interest Rate Environment?. Finance and Economics Discussion Series 2017-030, Board of Governors of the Federal Reserve System (U.S.).

Arteta C., Kose A. M., Stocker M. and Taskin T., (2018). Implications of negative interest rate policies: An early assessment. Pacific Economic Review, Vol. 23, Issue , pp. 6-28.

Athanasoglou P. P., Brissimis S. N. and Delis M. D., (2008). Bank-specific, Industry-specific and Macroeconomic Determinants of Bank Profitability. Journal of International Financial Markets, Institutions and Money, Vol. 18, No. 2, pp. 121-136.

Basten C. and Mariathasan M., (2018). How Banks Respond to Negative Interest Rates: Evidence from the Swiss Exemption Threshold. CESifo Working Papers No. 6901, CESifo Group Munich.

Beck T. and Levine R., (2004). Stock markets, banks and growth: Panel evidence. Journal of Banking $\mathcal{E}$ Finance, Vol. 28, pp. 423-442.

Beck T., De Jonghe O. and Schepens G., (2013). Bank competition and stability: Cross-country heterogeneity. Journal of Financial Intermediation, Elsevier, Vol. 22(2), pp. 218-244.

Berger Allen N., Klapper L. F. and Turk-Ariss R., (2009). Bank Competition and Financial Stability. Journal of Financial Service Research, Vol. 35, issue 2, pp. 99-118.

Bikker J. and Vervliet T., (2018). Bank profitability and risk-taking under low interest rates. International Journal of Finance EEconomics, Vol. 23, Issue 1, pp. 3-18.

Blot C. and Hubert P., (2016). Negative interest rates: incentive or hindrance for the banking system? Monetary Dialogue, November 2016.

Blundell R. and Bond S., (1998). Initial conditions and moment restrictions in dynamic panel data models. Journal of Econometrics, Vol. 87, pp. 115-143. 
Bordo M. D. and Jeanne O., (2002). Monetary Policy And Asset Prices: Does 'Benign Neglect' Make Sense?. International Finance, 2002, Vol. 5(2, Summer), pp. 139-164.

Bordo M. D. and Landon-Lane J., (2013). "Does expansionary monetary policy cause asset price booms? Some historical and empirical evidence," Journal Econom ÃaChilena (The Chilean Economy), Central Bank of Chile, vol. 16, No. 2 (August 2013), pp. 04-52.

Borio C. and Gambacorta L., (2017). Monetary policy and bank lending in a low interest rate environment: Diminishing effectiveness?. Journal of Macroeconomics, Elsevier, Vol. 54(PB), pp. 217-231.

Borio C. and Zhu H., (2012). Capital regulation, risk-taking and monetary policy: A missing link in the transmission mechanism?. Journal of Financial Stability, Elsevier, Vol. 8, No. 4, pp. 236-251.

Borio C., Gambacorta L. and Hofmann B., (2017). The influence of monetary policy on bank profitability. International Finance, Wiley Blackwell, Vol. 20, No. 1, pp. 48-63, March.

Bottero M., Minoiu C., Peydro J-L., Polo A., Presbitero A. F., and Sette E., (2019). Negative Monetary Policy Rates and Portfolio Rebalancing: Evidence from Credit Register Data. IMF Working Paper, WP/19/44.

Boyd J. H. and Graham S. L., (1986). Risk, regulation, and bank holding company expansion into nonbanking. Federal Reserve Bank of Minneapolis. Quarterly Review, 10, pp. 2-17.

Boyd J. H., Graham S. L., and Hewitt R. S., (1993). Bank holding company mergers with nonbank financial firms: Effects on the risk of failure. Journal of Banking \& Finance, Vol. 17, issue 1, pp. 43-63.

Busch R. and Memmel C., (2017). Banks' Net Interest Margin and the Level of Interest Rates. Credit and Capital Markets- Kredit und Kapital. Vol. 50, No. 3, pp. 63-392.

Camara B., Lepetit L. and Hoffman B., (2013). Ex ante capital position, changes in the different components of regulatory capital and bank risk. Applied Economics, Vol. 45, No. 34, pp. 48314856.

Caselli G., (2016). Monetary policy, bank risk taking and financial stability: The role of biodiversity' in European banking. Cranfield School of Management.

Čihák M. and Hesse H., (2007). Cooperative Banks and Financial Stability. IMF Working Papers 07/2, International Monetary Fund.

Claessens S., Coleman N., and Donnelly M., (2018). "Low-For-Long” Interest Rates and Banks' Interest Margins and Profitability: Cross-Country Evidence. Journal of Financial Intermediation, Vol. 35, Part A, pp. 1-16.

Coeuré B., (2016). Assessing the implication of negative interest rate. Speech at the Yale Financial Crisis Forum in New Haven. July 28, 2016.

Cordella T. and Yeyati E. L., (2002). Financial opening, deposit insurance, and risk in a model of banking competition. European Economic Review, Vol. 46, issue 3, pp. 471-485.

Delis M. D. and Kouretas G., (2011). Interest rates and bank risk-taking. Journal of Banking \& Finance, Elsevier, Vol. 35, No. 4, pp.840-855, April.

Delis M.. D, Hasan, I. and Mylonidis, N., (2011). The risk-taking channel of monetary policy in the USA: Evidence from micro-level data. MPRA Paper 34084, University Library of Munich, Germany.

Dell'Ariccia G., Laeven L. and Suarez G. A., (2017). Bank Leverage and Monetary Policy's Risk-taking Channel: Evidence from the United States. Journal of Finance, American Finance Association, Vol. 72, No. 2, pp. 613-654, April.

Demirgüç-Kunt A. and Huizinga H., (1999). Determinants of Commercial Bank Interest Margins and Profitability: Some International Evidence. World Bank Economic Review, World Bank Group, Vol. 13, No. 2, pp. 379-408, May.

Demsetz R. S., Saidenberg M. R. and Strahan P. E., (1996). Banks with Something to Lose: The Disciplinary Role of Franchise Value. Economic Policy Review, Issue October, pp. 1-14.

Eisenschmidt J. and Smets F., (2018). Negative interest rates: Lessons from the Euro Area. Mimeo

Espinoza R. and Prasad A., (2010). Nonperforming Loans in the GCC Banking System and their Macroeconomic Effects. IMF Working Paper, WP/10/224.

Gambacorta L., (2009). Monetary policy and the risk-taking channel. BIS Quarterly Review, Bank for International Settlements, December. 
Garcia-Herrero E., Gavilá S. and Santabárbara D., (2009). What Explains the Low Profitability of Chinese Banks?. Journal of Banking \& Finance, Elsevier, Vol. 33, No. 11, pp. 2080-2092, November.

Genay H. and Podjasek R., (2014). What is the impact of a low interest rate environment on bank profitability?. Chicago Fed Letter, July 2014, No. 324.

Geng Z., Grivoyannis E. and Zhang S., (2016). The effects of the interest rates on bank risk in China: A panel data regression approach. International Journal of Engineering Business Management, Vol. 8, pp. 1-7.

Hancock D., (1985). The Financial Firm: Production with Monetary and Nonmonetary Goods. Journal of Political Economy, Vol. 93, No. 5 (Oct., 1985), pp. 859-880

Hannan T. and Hauweck G., (1988). Bank Insolvency Risk and the Market for Large Certificates of Deposit. Journal of Money, Credit and Banking, Vol. 20, Issue 2, pp. 203-211.

Hannoun, H. (2015). Ultra-low or negative interest rates: what they mean for financial stability and growth. Speech given at the BIS Eurofi High-Level Seminar in Riga, 22 April 2015.

Heider F., Saidi F. and Schepens G., (2018). Life Below Zero: Bank Lending Under Negative Policy Rates. ECB Working Paper No. 2173.

Holtz-Eakin D., Newey W. and Rosen H. S., (1988). Estimating Vector Autoregressions with Panel Data. Econometrica, Vol. 56, No. 6 (Nov., 1988), pp. 1371-1395.

Houston J. F., Lin C. and Lin P., (2010). Creditor Rights, Information Sharing, and Bank Risk-taking. Journal of Financial Economics, Vol. 96, No. 3 (June 2010), pp. 485-512.

Ioannidou V., Steven Ongena S., and \& José-Luis Peydró, (2015). "Monetary Policy, Risk-Taking, and Pricing: Evidence from a Quasi-Natural Experiment. Review of Finance, European Finance Association, vol. 19(1), pages 95-144.

Jensen M. C. and Meckling W. H., (1976). Theory of the Firm: Managerial Behavior, Agency Costs and Ownership Structure. Journal of Financial Economics, Vol. 3, No. 4, pp. 305-360.

Jeon N. B., Guo M., Chen M. and Wu J., (2018). Market power and the risk-taking of banks: Some semiparametric evidence from emerging economies. LeBow College of Business Drexel University School of Economics. Working Paper Series, WP 2018-01.

Jiménez G., Lopez J. A. and Saurina J., (2013). How does competition affect bank risk-taking?. Journal of Financial Stability, Vol. 9, issue 2, pp. 185-195.

Jiménez G., Ongena S., Peydró J-L. and Saurina J., (2014). Hazardous Times for Monetary Policy: What Do Twenty- Three Million Bank Loans Say About the Effects of Monetary Policy on Credit Risk- Taking?. Econometrica, Vol. 82, issue 2, pp. 463-505.

Jobst Andreas (Andy) and Lin Huidan, (2016). Negative Interest Rate Policy (NIRP): Implications for Monetary Transmission and Bank Profitability in the Euro Area. IMF Working Paper No. 16/172. Available at SSRN: https://ssrn.com/abstract=2882609

IMF (2016). Euro Area Policies. IMF Country Report N¹6/219 (July 2016).

Keeley M. C., (1990). Deposit Insurance, Risk, and Market Power in Banking. The American Economic Review, Vol. 80, No.5 (Dec., 1990), pp. 1183-1200.

Kerbl S. and Sigmund M., (2017). Negative Interest Rates: Forecasting Banks' Profitability in a New Environment. SSRN Electronic Journal (Forthcoming)

Klein P-O. and Weill L., (2018). Bank profitability and economic growth. BOFIT Discussion Papers 15/2018. Bank of Finland, Institute for Economies in Transition.

Kosmidou K., (2008). The determinants of banks' profits in Greece during the period of EU financial integration. Managerial Finance, Vol. 34, No. 3, pp. 146-159.

Kosmidou K., Tanna S. and Pasiouras F., (2008). Determinants of profitability of domestic UK commercial banks: panel evidence from the period 1995-2002. Economics, Finance and Accounting Applied Research, Working Paper No. RP08-4.

Laeven L. and Levine Ross (2009). Bank governance, regulation and risk taking. Journal of Financial Economics, Elsevier, Vol. 93, No. 2, pp. 259-275.

Laeven L., Ratnovski L. and Tong H., (2016). Bank size, capital. and systemic risk: Some international evidence. Journal of Banking \& Finance, Vol. 29, Issue S1, S25 - S35.

Madaschi C. and Nuevo I. P., (2017). The profitability of banks in a context of negative monetary policy rates: the cases of Sweden and Denmark. European Central Bank. Occasional Paper Series, No. 195/ August 2017. 
Maddaloni A. and Peydró J-L., (2011). Bank Risk-Taking, Securitization, Supervision and Low Interest Rates: Evidence from the Euro Area and the U.S. Lending Standards. Review of Financial Studies, Vol. 24, Issue 6, pp. 2121-2165.

Martynova N., Ratnovski L. and Vlahu R., (2015). Bank Profitability and Risk-Taking. IMF Working Paper, WP/15/249.

Michalak T. C., (2012). The nexus between monetary policy, banking market structure and bank risk taking. In M. Balling, \& D. T. Llewellyn (Eds.), New paradigms in monetary theory and policy?. The European Money and Finance Forum, SUERF Study 2012/1, pp. 187-232.

Molyneux P., Reghezza A. and Xie R., (2018). Bank Profits and Margins in a World of Negative Rates. Bangor Business School, Prifysgol Bangor University (Cymru/Wales), Working Paper BBSWP $/ 18 / 01$.

Nguyen T. V. H. and Boateng A., (2015). An analysis of involuntary excess reserves, monetary policy and risk-taking behaviour of Chinese Banks. International Review of Financial Analysis, No. 37, pp. 63-72.

Noman H. A., Chowdhury M. M., Chowdhury N. J., Kabir M. J. and Pervin S., (2015). The Effect of Bank Specific and Macroeconomic Determinants of Banking Profitability: A Study on Bangladesh. International Journal of Business and Management, Vol. 10, No. 6.

Pham M. D., (2016). Size, Ownership Structure and Risk-taking Behavior: An Empirical Study of Vietnamese Commercial Banks. Available at SSRN: https:// ssrn.com/abstract=2864261

Rahman M. M., Zheng C. and Ashraf N., (2015). Bank Size, Risk-taking and Capital Regulation in Bangladesh. Eurasian Journal of Business and Economics, Vol. 8, No. 15, pp. 95-114.

Rajan R. G. (2006). Has Finance Made the World Riskier? European Financial Management, Vol. 12, Issue 4, pp. 499-533.

Repullo R., (2004). Capital Requirements, Market Power, and Risk-Taking in Banking. Journal of Financial Intermediation, Elsevier, Vol. 13, $\quad$ Issue 2 (April 2004), pp. 156-182.

Roy A. D., (1952). Safety First and Holding of Assets. Economica, Vol. 20, No. 3 (Jul., 1952), pp. 431-449.

Scheiber T., Silgoner M. and Stern C., (2016). The development of bank profitability in Denmark, Sweden and Switzerland during a period of ultra-low and negative interest rates. Focus on European Economic Integration, OesterreichischeNationalbank (Austrian Central Bank), Issue 3, pp. 8-28.

Tabak B. M., Laiz M. T. and Cajueiro D. O., (2013). Financial Stability and Monetary Policy - The case of Brazil. RevistaBrasileira de Economia - RBE, FGV/EPGE - Escola Brasileira de Economia e Finanças, Getulio Vargas Foundation (Brazil), Vol. 67, No. 4, November.

Taylor J. B., (2009). The Financial Crisis and the Policy Responses: An Empirical Analysis of What Went Wrong. Critical Review: A Journal of Politics and Society, Vol.21, Issue 2-3, 2009 Special Issue: Causes of the Financial Crisis.

Trofimov I. D., Aris N. Md. and Ying Y. J. K., (2018). Determinants of Commercial Banks' Protability in Malaysia. Munich Personal RePEc Archive. MPRA Paper No. 85598.

Windmeijer F., (2005). Finite Sample Correction for the Variance of Linear Two-step GMM Estimators. Journal of Econometrics, Vol. 126, issue 1, pp. 25-51.

Ziadeh-Mikati N., (2013). Too Low for Too Long Interest Rates, Bank Risk Taking and Bank Capitalization: Evidence From the U.S. Commercial Banks. Available at: https://afse2013.sciencesconf.org/conference/afse2013/pages/ZIADEH.pdf

Zimmermann K., (2019). Monetary Policy and Bank Profitability, 1870-2015. January 25, 2019. Available at SSRN: https://ssrn.com/abstract $=3322331$ 


\section{ABOUT OFCE}

The Paris-based Observatoire français des conjonctures économiques (OFCE), or French Economic Observatory is an independent and publicly-funded centre whose activities focus on economic research, forecasting and the evaluation of public policy.

Its 1981 founding charter established it as part of the French Fondation nationale des sciences politiques (Sciences Po), and gave it the mission is to "ensure that the fruits of scientific rigour and academic independence serve the public debate about the economy". The OFCE fulfils this mission by conducting theoretical and empirical studies, taking part in international scientific networks, and assuring a regular presence in the media through close cooperation with the French and European public authorities. The work of the OFCE covers most fields of economic analysis, from macroeconomics, growth, social welfare programmes, taxation and employment policy to sustainable development, competition, innovation and regulatory affairs.

\section{ABOUT SCIENCES PO}

Sciences $\mathrm{Po}$ is an institution of higher education and research in the humanities and social sciences. Its work in law, economics, history, political science and sociology is pursued through ten research units and several crosscutting programmes.

Its research community includes over two hundred twenty members and three hundred fifty PhD candidates. Recognized internationally, their work covers a wide range of topics including education, democracies, urban development, globalization and public health.

One of Sciences Po's key objectives is to make a significant contribution to methodological, epistemological and theoretical advances in the humanities and social sciences. Sciences Po's mission is also to share the results of its research with the international research community, students, and more broadly, society as a whole. 